\title{
Christian Wiikmann
}

Avaliação da viscosidade dinâmica de materiais implantáveis em pregas vocais: comparação entre camada superficial de fáscia temporal, camada profunda de fáscia temporal e gordura abdominal

Tese apresentada à Faculdade de Medicina da Universidade de São Paulo para obtenção do título de Doutor em Ciências

Área de concentração: Otorrinolaringologia Orientador: Prof. Dr. Luiz Ubirajara Sennes

São Paulo 
Dados Internacionais de Catalogação na Publicação (CIP)

Preparada pela Biblioteca da

Faculdade de Medicina da Universidade de São Paulo

Creprodução autorizada pelo autor

\section{Wiikmann, Christian}

Avaliação da viscosidade dinâmica de materiais implantáveis em pregas vocais: comparação entre camada superficial de fáscia temporal, camada profunda de fáscia temporal e gordura abdominal / Christian Wiikmann. -- São Paulo, 2009.

Tese(doutorado)--Faculdade de Medicina da Universidade de São Paulo.

Departamento de Oftalmologia e Otorrinolaringologia.

Área de concentração: Otorrinolaringologia.

Orientador: Luiz Ubirajara Sennes.

Descritores: 1.Laringe 2.Pregas vocais 3.Reologia 4.Viscosidade 5.Fáscia

6.Gordura abdominal 
"As teorias científicas não estarão nunca aptas a fornecer uma descrição completa e definitiva da realidade. Serão sempre aproximações da verdadeira natureza das coisas. Em termos claros: os cientistas não lidam com a verdade; eles lidam com descrições da realidade limitadas e aproximadas” 
Dedico este trabalho

A Deus, que é tudo que há. A meus pais, Nelson e Maria Rosa, que me tornaram vivo. À minha irmã, Vivian, em quem me espelho e ao Luiz, que a acompanha. Ao amor ainda desconhecido e aos filhos ainda não nascidos, pela esperança. 


\section{AGRADECIMENTOS}

Agradeço ...

Ao meu orientador, Prof. Dr. Luiz Ubirajara Sennes, pela oportunidade de realizar este trabalho e por sua orientação completamente precisa, participativa e calorosa. Ademais, sua visão totalmente lúcida da medicina contagia quem possa conviver com ele.

À Profa. Dra. Elizabeth Gomes Pinheiro Arêas e ao Dr. Marcelo Alves da Silva, do Laboratório de Biofísico-Química do Instituto de Química da Universidade de São Paulo, pela inestimável contribuição, pelos ensinamentos valiosos e pelo tempo e esforço utilizados na realização deste trabalho.

Ao Prof. Dr. Domingos Hiroshi Tsuji, pela idéia original deste trabalho. Não há limites para sua curiosidade, criatividade e excelência.

Ao Dr. Rui Imamura, cujo espírito de luta inspirou cada momento da minha formação otorrinolaringológica.

Ao Dr. Ronaldo Frizzarini, a quem tentar descrever o porquê de um agradecimento poderia parecer falta de respeito.

Ao Dr. Gilberto Guanaes Simões Formigoni. Tive vários ótimos professores, mas só um mestre.

À Dra. Vera Lúcia Ribeiro Fuess, cuja alegria e inteligência inspiram a renovação das forças. 
Ao Prof. Dr. Ricardo Ferreira Bento, cujo empreendedorismo contribuiu decisivamente para que a Disciplina de Otorrinolaringologia da FMUSP fosse o que é hoje.

Ao Prof. Dr. Ossamu Butugan, verdadeiro paradigma de ética, transparência e empatia profissionais.

Ao Prof. Dr. Aroldo Miniti, por ter me acolhido muito bem em sua clínica, em 1999.

Ao Dr. Flavio Akira Sakae, pelos anos de convivência dentro da laringologia, por todos os "apuros" em que nos metemos juntos e pelo aprendizado que derivou disso.

Ao Dr. Ali Mahmoud. Partilhamos o amor pela mesma subespecialidade e pelo mesmo time de futebol. Ali e sua esposa, Renata Lorencetti, são grandes amigos.

Ao Dr. Flavio Augusto Passarelli Prado. Impossível precisar sua influência em meu trabalho, minha formação e minha vida. Flavio e sua esposa, Patrícia Pontes Passarelli Prado e agora o pequeno Henrique moram no meu coração.

À Dra. Lucinda Simoceli, por toda a cumplicidade que desenvolvemos durante nossos anos de trabalho em conjunto, principalmente durante nossa preceptoria em comum. Sua coragem contagia.

Ao Dr. Daniel Chung, amigo ao longo da faculdade, da residência e da vida.

Aos Drs. Patrícia Paula Santoro, Fernando Angélico Veiga Filho e Arthur Menino Castilho, pela dedicação com que realizaram suas preceptorias. Ser preceptor é padecer no paraíso. 
Aos Drs. José Alexandre Médicis de Oliveira, Oswaldo Martucci Júnior e Silvio Marone, pela calorosa acolhida no Hospital Santa Marcelina.

Aos profissionais do Grupo de Voz do HCFMUSP, Dra. Natasha Mascarenhas Braga, Dra. Saramira Bahadana, Dra. Luciana Miwa Nita, Dra. Adriana Hachiya, Dr. Rafael Cahali, Dr. Henry Ugadin Kiyoshi, Dr. Luiz Antonio Prata Figueiredo e Fga. Gabriela Cunha pela contribuição em nosso aprendizado.

Aos residentes e ex-residentes do HCFMUSP e do Hospital Santa Marcelina, cujo convívio estimula a curiosidade.

Aos colaboradores do Departamento de Otorrinolaringologia do HCFMUSP, Edzira Centini (Edzira), Lucivania Lima da Silva (Luci), Maria Marcia Alves (Marcinha), Maria Marilede Alves (Leide) e Jorge Dias Barbosa (Jorjão), pela inestimável ajuda durante todo o meu período de formação.

À Coordenação de Aperfeiçoamento Pessoal de Nível Superior, CAPES, pelo apoio financeiro.

A todas as pessoas que são ou foram meus pacientes. $\mathrm{O}$ objetivo principal deste trabalho e de toda a formação é poder atendê-los cada vez melhor.

Ao cadáver desconhecido. Tudo tem um fim. A morte é a única certeza. Espero que sua vida tenha sido luminosa. 


\section{SUMÁRIO}

Lista de abreviaturas $\quad x$

Lista de símbolos e siglas $\quad$ xi

Lista de figuras $\quad$ xii

Lista de tabelas

Resumo xiv

$\begin{array}{lll}\text { Summary } & \mathrm{XV}\end{array}$

Artigo publicado no Ann Otol Rhinol Laryngol. 2009;118:461-4 xvi

The Laringoscope - Instructions to authors $\quad \mathrm{xx}$

$\begin{array}{ll}\text { Artigo } & \text { xxix }\end{array}$

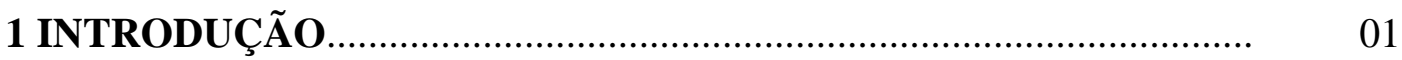

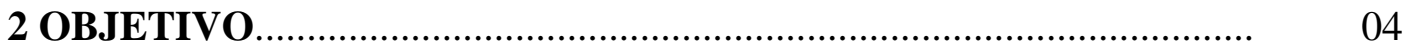

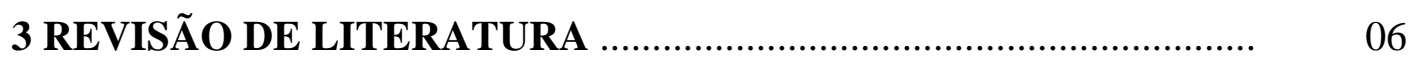

3.1 Estudos de viscosidade de pregas vocais normais ............................... 07

3.2 Estudos de viscosidade de pregas vocais alteradas .............................. 08

3.3 Viscosidade de materiais implantáveis em pregas vocais ....................... 11

3.4 Sobre o método de medição de propriedades viscoelásticas em pregas vocais e materiais implantáveis ............................................................ 14

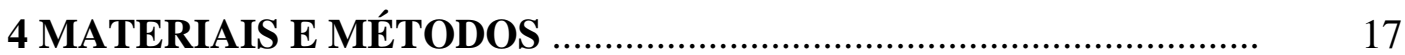

4.1 Obtenção das amostras ...................................................................... 18

4.2 Medições da viscosidade dinâmica (VD) ................................................ 19 


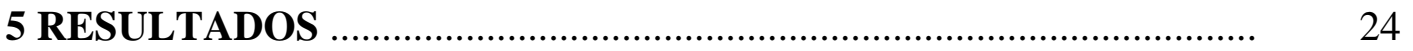

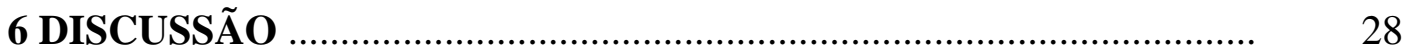

7 CONCLUSÃO .......................................................................... 36

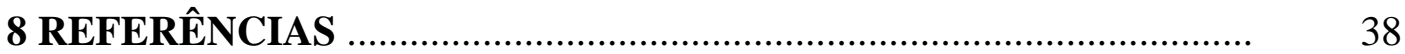

APÊNDICE 


\section{LISTA DE ABREVIATURAS}

$\begin{array}{ll}\text { CPFT } & \text { camada profunda da fáscia temporal } \\ \text { CSFT } & \text { camada superficial da fáscia temporal } \\ \text { CTE } & \text { células tronco embrionárias } \\ \text { CTMH } & \text { células tronco mesenquimais humanas } \\ \text { HC-FMUSP } & \text { Hospital das Clínicas da Faculdade de Medicina da Universidade } \\ & \text { de São Paulo } \\ \text { STT } & \text { sobreposição tempo-temperatura } \\ \text { VD } & \text { Viscosidade dinâmica }\end{array}$


LISTA DE SÍMBOLOS E SIGLAS

$\begin{array}{ll}\mathrm{cm} & \text { centímetro } \\ \mathrm{Hz} & \text { Hertz } \\ \mathrm{mm} & \text { milímetro } \\ \mathrm{N} & \text { Newton } \\ \mathrm{Pa} & \text { Pascal } \\ \mathrm{S} & \text { segundo } \\ < & \text { menor } \\ > & \text { maior }\end{array}$




\section{LISTA DE FIGURAS}

Figura 1 Reômetro Paar-Physica MCR 300 (Paar Physica, Stuttgart, Alemanha)

Figura 2 Representação esquemática das placas paralelas, cujos parâmetros indicativos principais são: $F$ = força torcional aplicada sobre a área da placa (A); $\mathrm{h}$ = espaçamento entre placas; $\mathrm{N}_{1}=$ força normal.

Figura 3 Fragmento de camada superficial de fáscia temporal sobre placa fixa do reômetro. A placa móvel encontra-se suspensa (A); fragmento de camada superficial de fáscia temporal entre as placas do reômetro, ainda sem óleo mineral (B)

Figura 4 Curvas de viscosidade dinâmica média $\left(\mathrm{VD}_{\mathrm{M}}\right)$ para cada tipo de tecido, para as diferentes faixas de frequência. Cada ponto representa a média dos valores da viscosidade dinâmica para 12 amostras em cada intervalo de frequência. O eixo da viscosidade dinâmica está em escala logarítmica. 


\section{LISTA DE TABELAS}

Tabela 1 Viscosidade dinâmica média para cada tipo de tecido para as diferentes faixas de frequência (12 amostras/faixa).

Tabela 2 Resultados da análise estatística em comparações múltiplas entre os valores da viscosidade dinâmica de tecidos diferentes, com relação aos intervalos de frequência............................................. 


\section{RESUMO}

Wiikmann C. Avaliação da viscosidade dinâmica de materiais implantáveis em pregas vocais: comparação entre camada superficial da fáscia temporal, camada profunda da fáscia temporal e gordura abdominal [tese]. São Paulo: Faculdade de Medicina, Universidade de São Paulo; 2009. 85 pág.

OBJETIVO: Comparar a viscosidade dinâmica da camada superficial da fáscia temporal com a de outros tecidos biológicos tradicionalmente utilizados em implantes de pregas vocais para o tratamento de rigidez de pregas vocais. DESENHO DO ESTUDO: Experimental. MÉTODO: Amostras de camada superficial da fáscia temporal, camada profunda da fáscia temporal e gordura abdominal de 12 cadáveres são submetidas a medição de viscosidade dinâmica. RESUTADOS: A viscosidade dinâmica das diferentes amostras apresenta-se na seguinte ordem crescente: camada superficial da fáscia temporal, camada profunda da fáscia temporal e gordura abdominal. Observa-se diferença estatística na comparação entre todas as amostras. DISCUSSÃO: Quanto maior for a viscosidade da mucosa da prega vocal, maior é a pressão subglótica necessária para se iniciar a fonação. Dessa maneira, um bom material implantável em lâmina própria de prega vocal deve ter baixa viscosidade. Por esse parâmetro, a camada superficial da fáscia temporal é um material promissor para implantação em pregas vocais. CONCLUSÃO: A viscosidade dinâmica da camada superficial da fáscia temporal é menor que a da camada profunda da fáscia temporal e que a da gordura abdominal.

DESCRITORES: Laringe, pregas vocais, reologia, viscosidade, fáscia, gordura abdominal. 


\section{SUMMARY}

Wiikmann C. Evaluation of dynamic viscosity of implantable materials into vocal folds: comparison among superficial layer of temporalis fascia, deep layer of temporalis fascia and abdominal fat [thesis]. Sao Paulo: "Faculdade de Medicina, Universidade de São Paulo”; 2009. 85 pp.

OBJECTIVE: To compare the dynamic viscosity of superficial layer of temporalis fascia with that of other biological tissues traditionally used for vocal fold implants to treat vocal fold rigidity. STUDY DESIGN: Experimental. METHOD: Measurement of dynamic viscosity of samples of superficial layer of temporalis fascia, deep layer of temporalis fascia and abdominal fat of 12 cadavers are performed. RESULTS: Dynamic viscosity values of the different samples are presented in the following increasing order: superficial layer of temporalis fascia, deep layer of temporalis fascia and abdominal fat. There is statistical difference among all the samples. CONCLUSION: Dynamic viscosity of superficial layer of temporalis fascia is lower than the ones of deep layer of temporalis fascia and abdominal fat.

DESCRIPTORS: Larynx, vocal folds, rheology, viscosity, fascia, abdominal fat. 


\title{
Annals of Otology, Rhinology \& Laryngology
}

Annals of Otology, Rhinology \& Laryngology 118(6):461-464

O 2009 Annals Publishing Company. All rights reserved.

\section{Measurement of the Viscoelastic Properties of the Vocal Folds}

\author{
Christian Wiikmann, MD; Marcelo Alves da Silva, $\mathrm{PhD}$; \\ Elizabetli Pinheiro Gomes Arêas, PhD; Domingos Hiroshi Tsuji, MD, PhD; \\ Luiz Ubirajara Sennes, MD, $\mathrm{PhD}$
}

\begin{abstract}
Objectives: Studies of the viscoelastic properties of the vocal folds are normally performed with rheometers that use parallel plates whose interplate space is usually arbitrarily assigned a fixed value. In tissues subject to variation of thickness between samples, fixed gaps could result in different compressions, compromising the comparison among them. We performed an experimental study to determine whether different compressions can lead to different results in measurements of dynamic viscosity (DV) of vocal fold samples.
\end{abstract}

Methods: We measured the DV of vocal fold samples of 10 larynges of cadavers under 3 different compression ievels, corresponding to $0.2,0.5$, and $10 \mathrm{~N}$ on an 8 -mm-diameter parallel-plate rheometer

Results: The DV directly varied with compression. We observed statisically significant differences between the results of 0.2 and $10 \mathrm{~N}(\mathrm{p}=0.0396)$ and 0.5 and $10 \mathrm{~N}(\mathrm{p}=0.0442)$.

Conclusions: The study demonstrated that the level of compression influences the DV measure and suggests that a defined compression level should be used in rheometric studies of biological tissues.

Key Words: larynx, rheology, rheometer, viscosity, vocal fold.

\section{INTRODUCTION}

Poor vocal fold mucosa vibration leading to poor vocal quality represents a major challenge in laryngology. ${ }^{1}$ It is usually the result of lamina propria disorders (cysts, sulcus) or adherence to the vocal ligament (scar after surgery or trauma). Surgical treatment is based on recovery of the lamina propria, using implantation of biological or synthetic materials between the epithelium and the vocal ligament, thus creating a pad over which the epithelium can more easily vibrate and produce a better voice quality. ${ }^{2}$

Many materials can be used for vocal fold implants, ${ }^{3}$ and many factors should be considered in such a choice: easy technique, ${ }^{4}$ immunogenicity, risk of migration, reabsorption, cost, and rheological properties. ${ }^{5}$

The lower the viscosity of the material, the lower its resistance to flow. ${ }^{5}$ It has been demonstrated that the greater the viscosity of the vocal fold mucosa, the greater the subglottic pressure necessary to trigger phonation. ${ }^{7}$ So, the use of less-viscous naterials could favor hetter postoperative results. ${ }^{8-11}$

In a standard rheological experimental study, the material is placed between 2 parallel plates in a rhe- ometer, as shown in Fig 1. The moving plate (superior) applies a controlled torsion force, and the mechanical response of the material to this perturbation is recorded. The dynamic viscosity (DV) is a measure of the resistance of the material to the deformation applied to it. It is expressed by the ratio between the applied stress and the shear rate or velocity gradient (Fig 1).

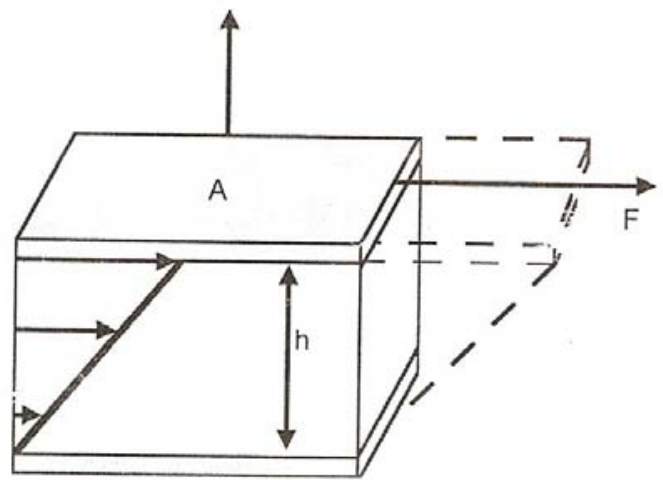

Fig 1. Schematic representation of parallel plates whose main indicative parameters were shear force (F) applied over plate area (A), and gap between plates (h).

From the Disciplina de Otorrinolaringologia da Faculdade de Medicina da Universidade de São Paulo (Wiikmann, Tsuji, Sennes), and

the Laboratório de Biofísico-Química do Instituto de Química da Universidade de São Paulo (Silva, Arêas). São Paulo, Brazil.

Presented at the XXXIX Brazilian Congress of Otorhinolaryngology. Belo Horizonte. Brazil, A pril 2, 2008.

Correspondence: Christian Wiikmann, MD, Rua Cristiano Viana, 671 ap 151,05411-001 São Paulo SP, Brazil. 
For less-deformable systems that do not adjust to the geometry imposed by plates, the gap between the plates can be determined in 2 different ways: 1 ) by defining a constant gap that best represents the average of the assayed samples; and 2) by adopting a defined compression that will result in variable gaps for sitmples of variable thickness. In the first case, there may be different resulting values of normal force $(\mathrm{F} n)$, whereas in the second case, the appropriate variation of gap will ensure similar values of $F n$. The use of interplate spacing conditions that generate the same value of $\mathrm{F} n$ ensures that the same conditions of compression are being imposed on different samples, even when the thicknesses are discrepant. When we study materials of variable thickness using the same gap, we are submitting the different samples to different levels of compression, resulting in different conditions of internal tension, which can influence the measured viscosity and thus lead to a misleading comparison between the samples.

To our knowledge, there are no articles in the literature that address rheology in laryngology studies that have used controlled spacing for compression. The purpose of the present study was to examine the variability of the DV of vocal fold mucosa submitted to different compressions.

\section{MATERIALS AND METHODS}

Samples werc acquired from the Department of Pathology of the University of São Paulo, after approval of the internal Research Ethics Committee. Larynges from 10 cadavers ( 5 male and 5 female, ages ranging from 34 to 87 years) were removed within 18 hours after death and placed in cold saline solution to be transported to the dissection laboratory.

The mucosa of both vocal folds (epithelium and superficial layer of lamina propria) was removed by a microsurgical technique under a surgical microscopic view (25× magnification). We excluded larynges that presented any observable lesion. After removal, the mucosa was placed in cold sterile saline solution to await the measurements, which were made on the same day.

We used rheemeter Physica MCR 300 (Paar Physica, Stuttgart, Germany) with 8-mm parallel plates. We performed frequency screenings from 0.1 to $2 \mathrm{~Hz}$, with $0.4 \%$ deformation in all samples. We collected 70 experimental points for each sample, distributed within the frequency range. The experiments were performed at $37^{\circ} \mathrm{C}$, with precision over $0.05^{\circ} \mathrm{C}$, through a Peltier system. They were all per- formed within the linear viscoelastic region of the sample, as defined by previous experiments we performed (data not shown) of strain amplitude sweep.

In each measurement, we used the product of dissection of the two vocal folds in each larynx at the same time, so that the whole area of the moving plate of the rheometer was in contact with the tissue - an essential condition for comparing the samples. Coherent patterns of rheological response, with oscillations well within the acceptable experimental error, were observed, minimizing the possibility of slippage effects. We placed mineral oil on the border of the measurement plate to prevent drying of the sample, which could result in increased DV.

For each sample, we performed 3 measurements, with gaps defined by 3 different compressions, with $\mathrm{F}_{n}$ registered as $0.2,0.5$, and $10 \mathrm{~N}$. That has allowed us to assess whether there was variation in the measurement of DV when the compression was increased. These compressions were arbitrarily chosen within the limits of the equipment operation, and corresponded to strain values in the linear viscoelastic region of samples so as to ensure sample integrity. Our previous experiments (data not shown) demonstrated that repeated measurements made within the linear viscoelastic region did not impair the integrity of the sample. It must be noted that the compressions were applied in increasing order, ie, from lower to higher compression values, for each tested sample. Ideally, the order of compression levels should have been randomized.

To compare the results of DV of vocal fold samples undergoing different compressions $(0.2,0.5$, and $10 \mathrm{~N}$ ), we used an analysis of variance with repeated measures. The level of significance adopted was $5 \%$.

\section{RESULTS}

Seventy measurements of DV per compression per sample were acquired as a function of frequency. The Table shows the mean DV in specific frequency interval for each compression, considering the 10 samples. A graphic representation of the mean DV curves for each compression level can be seen in Fig 2.

The measurements of mean DV weie directly proportional to the increase in compression. Multiple comparisons, independent of frequency range, indicated that the differences between results at 0.2 and $10 \mathrm{~N}$ were statistically significant $(\mathrm{p}=0.0396)$, as were those between results at 0.5 and $10 \mathrm{~N}(\mathrm{p}=$ 0.0442 ). There was no statistically significant difference between results at 0.2 and $0.5 \mathrm{~N}(\mathrm{p}=0.9564)$. 


\begin{tabular}{|c|c|c|c|c|c|c|}
\hline \multirow{2}{*}{$\begin{array}{l}\text { Frequency } \\
\text { Range }(\mathrm{Hz})\end{array}$} & \multicolumn{2}{|c|}{$0.2 \mathrm{~N}$} & \multicolumn{2}{|c|}{$0.5 \mathrm{~N}$} & \multicolumn{2}{|c|}{$10 \mathrm{~N}$} \\
\hline & Mean & $S D$ & Mean & $S D$ & Mean & $S D$ \\
\hline$>0.1-0.2$ & 10.26 & 4.23 & 22.36 & 17.62 & 464.51 & 772.43 \\
\hline$>0.2-0.3$ & 4.97 & 2.44 & 12.24 & 11.94 & 270.12 & 448.05 \\
\hline$>0.3-0.4$ & 4.06 & 1.82 & 7.65 & 4.92 & 173.22 & 305.15 \\
\hline$>0.4-0.5$ & 3.24 & 1.46 & 5.91 & 3.10 & 140.59 & 242.85 \\
\hline$>0.5-0.6$ & 2.46 & 1.15 & 5.22 & 3.77 & 114.35 & 197.00 \\
\hline$>0.6-0.7$ & 2.14 & 1.12 & 4.44 & 2.48 & 93.02 & 165.63 \\
\hline$>0.7-0.8$ & 2.01 & 0.82 & 4.16 & 1.78 & 88.35 & 156.79 \\
\hline$>0.8-0.9$ & 1.84 & 0.70 & 3.44 & 2.00 & 75.44 & 134.04 \\
\hline$>0.9-1$ & 1.71 & 0.65 & 3.00 & 1.72 & 66.50 & 119.28 \\
\hline$>1-2$ & 1.50 & 0.47 & 2.44 & 1.18 & 49.13 & 87.82 \\
\hline \multicolumn{7}{|c|}{ Data are pascals times seconds. } \\
\hline
\end{tabular}

\section{DISCUSSION}

The present study demonstrated that the compression placed over the vocal fold mucosa by the parallel plates of the rheometer influences the quantification of the DV. As demonstrated, the greater the exerted compression, the greater the DV.

In our opinion, this fact is extremely important when we are measuring shear viscoelastic properties in irregular biological tissues, such as the vocal fold mucosa. These tissues present great diversity of thickness, and if the gap between the plates is fixed, different samples will probably withstand different compressions, resulting in misleading comparisons between them. The use of a gap between the plates defined by specific compression may minimize this problem.

Studies have measured the viscoelastic properties of gels to be injected in the vocal folds. ${ }^{5,9,12}$ In such situations, it is possible to perform rheological measurements using fixed gaps, because such materials have a behavior relatively close to that of fluids. In such systems, as the gap is reduced, the compression of the sample tends to be constant, regardless of the material quantity, given that it overflows through the sides of the plates, relieving internal system terlsions. The upper plate of the system simply touches the sample surface without generating any perpendicular force $(\mathrm{F} n)$. That does not occur with structured or rigid solids, in which plate compression leacs to accumulation of internal tensions in the sample owing to its inability to be accommodated.

To minimize slipping or sliding of the sample in the measuring plate, minimum compression has to be necessarily applied to the system. Although greater compression leads to better contact and better measurement, it also increases the tissue internal tensions, thus altering the tissue's characteristics.

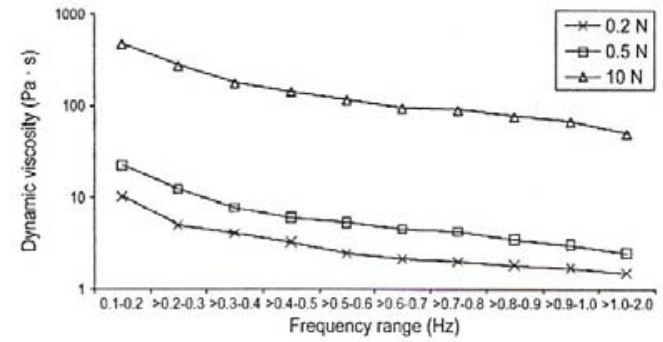

Fig 2. Graphic representation of mean dynamic viscosity curve for each compression level. Each spot represents mean dynamic viscosity of 10 samples along given frequency interval.

So, the optimal condition for measurement will be the best compromise between these two conditions.

The DV appeared as a decreasing function of frequency in all samples, in an almost linear logarithmic scale (Fig 2). This type of response was also observed in other studies. $1,13,14$

Analyzing Fig 2, we can observe that the DV means for different levels of compression of the samples are different and directly proportional to the applied compression, even though the results have not shown a statistically significant difference between 0.2 and $0.5 \mathrm{~N}$. A larger sample might have shown this difference, given that DV values vary greatly among the vocal folds of different larynges. ${ }^{1,13}$

Factors that explain the heterogeneity of DV between vocal mucosae of different subjects may include age, gender, smoking, differences in health status before death, exposure to irritant factors, and use of medications. ${ }^{13,15}$ It is interesting to point out that none of the vocal folds included in the present study had disorders observed under the surgical microscope.

Small-diameter rheometer plates $(8 \mathrm{~mm})$ were used, so that the mucosa of both vocal folds of the same cadaver was enough to fill the whole area of the plate.

In the present study, we used fresh samples of vocal folds no more than 18 hours after death, as it is established that the viscoelastic properties of vocal fold mucosa are maintained unaltered for up to 24 hours after death, ${ }^{16}$ thus preventing the possible effects that freezing could cause.

As seen in Fig 2, DV is a function of the frequency of oscillation. In this study, we used frequency screening between 0.1 and $2 \mathrm{~Hz}$, which is a much narrower range than that of vocal fold vibration during human phonation $(150$ to $250 \mathrm{~Hz})$. This is a limitation of the method used. At $3 \mathrm{~Hz}$, inertial effects ${ }^{13}$ 
and wall-slipping ${ }^{6}$ of the sample become significant, and the obtained data may not be reliable. In our study, this phenomenon occurred at much lower frequencies than in similar studies, ${ }^{13}$ in which inertia became significant at $15 \mathrm{~Hz}$. Different experimental conditions employed, such as plate dimensions, might account for differences in inertial effects. However, there are studies in the literature, in which a time-temperature superposition effect was used, that suggest the maintenance of the linear behavior of these systems in frequencies of the human phonation region, even though it is necessary to validate the application of time-temperature superposition to complex systems such as biological tissues. ${ }^{17-19}$

\section{CONCLUSIONS}

The present study demonstrated that the compression exerted on the vocal fold nucosa by the parallel plates of a rheometer may influence the quantification of its DV. This fact should be considered in studies on the viscoelastic properties of human tissues. Use of gap values defined by the level of compression of the plates on the sample is therefore recommended.

\section{REFERENCES}

1. Thibeault SL, Gray SD, Bless DM, Chan RW, Ford CN. Histologic and rheologic characterization of vocal fold scarring. J Voice 2002;16:96-104.

2. Dahlqvist $\mathrm{A}$, Gärskog $\mathrm{O}$, Laurent $\mathrm{C}$, Hertegård $\mathrm{S}, \mathrm{Am}$ brosio L, Borzacchiello A. Viscoelasticity of rabbit vocal folds after injection augmentation. Laryngoscope 2004;114:138-42.

3. Kriesel KJ, Thibeault SL, Chan RW, et al. Treatment of vocal fold scarring: rheological and histological measures of homologous collagen matrix. Ann Otol Rhinol Laryngol 2002; 111:884-9.

4. Hertegård S, Dahlquist $\mathrm{A}$, Laurent $\mathrm{C}$, Borzacchiello $\mathrm{A}$, Ambrosio L. Viscoelastic properties of rabbit vocal folds after augmentation. Otolaryngol Head Neck Surg 2003;128:401-6.

5. Chan RW, Titze IR. Viscosities of implantable biomaterials in vocal fold augmentation surgery. Laryngoscope 1998; 108: 725-31

6. Barnes HA, Hutton JI, Walters K. An introduction to rheology. Amsterdam, the Netherlands: Elsevier, 1989.

7. Titze IR. The physics of small-amplitude oscillation of the vocal folds. J Acoust Soc Am 1988;83:1536-52.

8. Chan RW, Titze IR. Hyaluronic acid (with fibronectin) as a bioimplant for the vocal fold mucosa. Laryngoscope 1999; 109:1142-9.

9. Chan RW, Gray SD, Titze IR. The importance of hyaluronic acid in vocal fold biomechanics. Otolaryngol Head Neck Surg 2001;124:607-14.

10. Rousseau B, Hirano S, Scheidt TD, et al. Characterization of vocal fold scarring in a canine model. Laryngoscope 2003;113:620-7.
11. Hansen JK, Thibeault SL, Walsh JF, Shu XZ, Prestwich GD. In vivo engineering of the vocal fold extracellular matrix with injectable hyaluronic acid hydrogels: early effects on tissue repair and biomechanics in a rabbit model. Ann Otol Rhinol Laryngol 2005;114:662-70.

12. Klemuk SA, Titze IR. Viscoelastic properties of three vocal-fold injectable biomaterials at low audio frequencies. Laryngoscope 2004;114:1597-603.

13. Chan RW, Titze IR. Viscoelastic shear properties of human vocal fold mucosa: measurement methodology and empirical results. J Acoust Soc Am 1999;106:2008-20.

14. Gray SD, Titze IR, Alipour F, Hammond TH. Biomechanical and histologic observations of vocal fold fibrous proteins. Ann Otol Rhinol Laryngol 2000;109:77-85.

15. Ximenes Filho JA, Tsuji DH, do Nascimento PHS, Sennes LU. Histologic changes in human vocal folds correlated with aging: a histomorphometric study. Ann Otol Rhinol Laryngol 2003:112:894-8.

16. Chan RW, Titze IR. Effect of postmortem changes and freezing on the viscoelastic properties of vocal fold tissues. Ann Biomed Eng 2003;31:482-91.

17. Chan RW, Titze IR. Viscoelastic shear properties of human vocal fold mucosa: theoretical characterization based on constitutive modeling. J Acoust Soc Am 2000;107:565-80.

18. Chan RW. Estimation of viscoelastic shear properties of vocal-fold tissues based on time-temperature superposition. J Acoust Soc Am 2001;110:1548-61.

19. Chan RW. Measurements of vocal fold tissue viscoelasticity: approaching the male phonatory frequency range. $J$ Acoust Soc Am 2004;115:3161-70. 


\section{The Laryngoscope}

\section{Instructions to Authors}

The Laryngoscope is an international peer-reviewed periodical dedicated to the advancement of patient care in otolaryngology-head and neck surgery. As such, The Laryngoscope publishes original articles relating to both the clinical and basic science aspects of otolaryngology-head and neck surgery. The Laryngoscope reserves the right to exclusive publication of all accepted manuscripts. We will not consider any manuscript previously published nor under review by another publication. Once accepted for review, the manuscript must not be submitted elsewhere. Unethical publishing such as plagiarism, undisclosed conflicts of interest, inappropriate authorship, and duplicate publication are forbidden. This includes publication in a non-otolaryngologic journal or in another language. In case of doubt, disclosure is essential and the editor is available for consultation. Transfer of copyright to The Laryngoscope is a prerequisite of publication. All authors must sign the copyright transfer form. (This does not preclude publication of abstracts in the transactions or proceedings of the various societies.)

Authors must disclose any financial relationship at the time of submission and must be updated by the authors prior to the time of publication. Information that could be perceived as potential conflict of interest must be stated, including personal relationships, interests, and affiliations over the past three years. This information includes, but is not limited to, grants or funding, employment, affiliations, patents, inventions, honoraria, consultancies, royalties, stock options/ownership, or expert testimony.

Manuscripts are subject to peer review and revision may be required as a condition of acceptance. These instructions apply to all submissions.

Manuscripts reporting original scientific investigation, both basic science and clinical reports, are required to use the manuscript format described under "Manuscript Format" unless otherwise directed. The Laryngoscope will consider for publication Contemporary Reviews, Scientific Reviews, Rapid Communications, Case Reports, Letters to the Editor, and "How I Do It" submissions (note manuscript format in each section).

Contemporary Review manuscripts should review topics of contemporary interest and importance, and ideally should address controversial issues by expressing both sides of the controversy. The review should be comprehensive and authoritative as reflected by a contemporary bibliography. The review should emphasize the best evidence currently available. We especially invite collaborative efforts by authors representing different points of view. The manuscript format should conform to the format described below (see Manuscript Preparation for original scientific manuscripts). Contemporary Review articles do not require a Materials/Methods or Results section.

Original Reports present data which has not yet been published. An emphasis is given for higher levels of evidence. The manuscript should be formatted in accordance with the structure described under "Manuscript Format" below. The abstract should be limited to 250 words. The level of evidence presented should be indicated at the end of the abstract.

Rapid Communications report information of importance to otolaryngology-head and neck surgery not suitable for presentation as a full-length manuscript. Rapid Communications should be limited to three double-spaced typewritten pages. An abstract and references are not required.

Case Reports describes encounters with one or several patients with unique or unusual clinical situations. The key to an acceptable Case Report is the identification of a clinical 
pearl or clinical wisdom that could benefit future patients. Case Reports should be limited to four double-spaced typewritten pages and no more than eight references. An abbreviated abstract limited to less than 100 words that captures the essential value of the Case Report should be included.

Letters to the Editor should be directed to the Editor regarding manuscripts previously published in which significant scientific controversy exists. Letters to the Editor deemed appropriate for publication will be submitted to the author(s) of the manuscript of interest comment. Letters to the Editor should be limited to three double-spaced type written pages including references.

"How I Do It" submissions report innovative solutions to clinical problems. Originality and quality of illustrations (when appropriate) are essential ingredients. "How I Do It" manuscripts should have a clear practical value and be no more than four double-spaced typewritten pages. An abstract is "required" in ScholarOne Manuscripts (http://mc.manuscriptcentral.com/lscope) as it enables the reviewer to see a summary of your paper and determine if they have the expertise to review it. An abstract "is not required" for the paper that is submitted for possible publication.

\section{Authorship Criteria and Responsibility}

The Laryngoscope insists that all authors are truly qualified to be listed as such. Others who have contributed to the work but are not qualified to be authors should be "acknowledged" at the end of the article.

Authorship credit is based only on having made a substantial contribution to the published work by virtue of meeting all the following three criteria:

1. Conception and design of project or analysis of the manuscript data;

2. Drafting or critically revising the content of the manuscript submitted for publication, and;

3. Giving final approval of the version to be published.

All three criteria must be met for an individual to be listed as an author or co-author on a published paper.

Please note that other criteria, which do not qualify an individual for "author status," include the following:

1. Supplying funding or other resources;

2. Collecting data (only);

3. General supervision of the research group, and;

4. Being departmental chair or division chief.

\section{Special Approval}

Manuscripts that include information obtained from human or animal research must include (in the text or an appropriate footnote) verification of the review and approval of the appropriate institutional research oversight committee for the work that is reported.

\section{Preparation of Manuscript}

Original scientific manuscripts and review articles that do not adhere to the following instructions will be returned to the corresponding author for technical revision before 
undergoing peer review. PLEASE NOTE: if you are not listed in the system as the "Corresponding Author," the submission will not show up in your queue for approval.

\section{Manuscript Submission}

Authors must submit their manuscript online through

http://mc.manuscriptcentral.com/lscope

Manuscripts submitted online are received on the day of submission and quickly assigned to reviewers. Through individual Author Centers on this website, authors can view the status of their manuscripts as they progress through the review process. Notification of the disposition of each manuscript will be sent by E-mail to the corresponding author on the day of decision. To submit your manuscript online:

- Go to http://mc.manuscriptcentral.com/lscope

- Click on the "Check for Existing Account" button at the bottom of the opening page. If you do not already have an account, then create one by clicking on the "Create an Account" button. You then will be able to submit your manuscript.

- Click on "Author Center." Follow the on-screen instructions carefully. Submit the complete manuscript with text (including references), tables, and figures as separate files. You do not need to mail paper copies of your manuscript.

- At the end of a successful submission, you will see a confirmation screen with your manuscript number, and you will receive a separate E-mail confirmation of manuscript reception by the journal. If these two messages do not appear, then go into your Author Center and make sure that you have clicked on the "Submit" button or contact technical support at support@scholarone.com.

Manuscript Format: The manuscript for the body of the text should not exceed 15 doublespaced typewritten pages. (Please see above additional requirements for Rapid Communication, "How I Do It," etc.)

The elements of a full-length article should be in the following sequence: Title Page, Structured Abstract and Key Words, Text (Introduction, Materials and Methods, Results, Discussion, Conclusion), Acknowledgment, References, Tables, and Figure Legends. (Note: all figures must be submitted as a separate attachment. Do not insert figures into the main document. "Attached Figures" must be identified within the "Text Portion" of the paper. The "Attached Figures" must be labeled [e.g., Figure 1, Figure 2, etc.] Authors may either type the label in the "Caption/Legend" box or add a text box onto each figure.) Each of these elements should begin on a new page, and each page should have a short running title (see next section: Title Page).

\section{Title pages:}

- "Online" Title page must be submitted as a separate file on the first page of the online system. This should contain: article title (not to exceed 75 characters, including spaces).

- "Formal" Title page must be submitted as part of your manuscript. This should contain: article title (not to exceed 75 characters, including spaces); names of authors, their degrees and affiliations (dept., institution, city, state, country); institution where the work was done (indicate which author is in which department); a short running title of no more than 45 letters and spaces; source of financial support or funding; and a footnote indicating the author to whom correspondence, reprint requests, and proofs will be sent, with complete address (including e-mail address and postal codes) and telephone and telefax numbers. If the paper was presented at a meeting, give society name, city, state, country, and exact date meeting was held. 
Financial Disclosure Information: The Title page must also include disclosure of funding: a. All financial and material support for this research and work.

b. Any financial interests the authors may have in companies or other entities that have an interest in the information in the Contribution (e.g., grants, advisory boards, employment, consultancies, contracts, honoraria, royalties, expert testimony, partnerships, or stock ownership in medically-related fields).

c. Indication of no financial disclosures, if appropriate. For example, please include "Conflict of Interest: None" if you have no conflicts to disclose.

Structured abstract and key words: Limit the abstract to 250 words. Do not cite references in the abstract. Limit the use of abbreviations and acronyms. Use the following subheads: Objectives/Hypothesis, Study Design (randomized, prospective, etc.), Methods, Results, and Conclusions.

New Required Information: Add to the submitted abstract "Level of Evidence." For more information, please click here.

Text: The text is to be divided into five sections with the following headings: Introduction, Materials and Methods, Results, Discussion, and Conclusion. Define abbreviations at first mention in text and in each table and figure. If a brand name is cited, supply the manufacturer's name and address (city and state/country). The introduction should be limited to two paragraphs of pertinent information. The discussion should not be an exhaustive review of the literature; it should be succinct and limited to conclusions that can be reached based on the results.

Abbreviations: Use generic names for drugs. List supplier of manufacturer for products and instruments; include supplier's city and state (e.g., Glaxo Wellcome, Research Triangle Park, NC). Audiograms must be plotted according to ISO standards and must be in black and white. For commonly accepted abbreviations, consult Logan's Medical and Scientific Abbreviations. Authors are encouraged to consult Dorland' Illustrated Medical Dictionary $\left(28^{\text {th }}\right.$ Edition), American Medical Association Manual of Style, and Council of Biology Editors Style Manual (available from the Council of Biology Editors, 9650 Rockville Pike, Bethesda, MD 20814, U.S.A.). The full term for which an abbreviation stands should precede its first use unless it is a standard unit of measurement.

Style: Pattern manuscript style after the American Medical Association Manual of Style $\left(9^{\text {th }}\right.$ Edition), Stedman's Medical Dictionary (27 $7^{\text {th }}$ Edition) and Merriam Webster's Collegiate Dictionary $\left(10^{\text {th }}\right.$ Edition) should be used as standard references. Refer to drugs and therapeutic agents by their accepted generic or chemical names, and do not abbreviate them. Use code numbers only when a generic name is not yet available. In that case, supply the chemical name and a figure giving the chemical structure of the drug. Capitalize the trade names of drugs and place them in parentheses after the generic names. To comply with trademark law, include the name and location (city and state in U.S.A.; city and country outside U.S.A.) of the manufacturer of any drug, supply, or equipment mentioned in the manuscript. Use the metric system to express the units of measure and degrees Celsius to express temperatures, and SI units rather than conventional units.

Permissions: The author is responsible for obtaining written permission to reproduce previously published material (direct quotations, unpublished data, tables, or figures) from the copyright holder. Enclose all letters granting permission at the time the manuscript is submitted for publication. Any permissions fees that might be required by the copyright owner are the responsibility of the authors requesting use for the borrowed material, not the responsibility of the Triological Society or Wiley-Blackwell. Photographs of recognizable persons must be accompanied by a signed release from the patient. For a photograph of a minor, signed parental permission is required. 
Internal Review: All authors are strongly encouraged to have their manuscripts thoroughly and critically reviewed within their institution before submitting to The Laryngoscope.

References: The authors are responsible for the accuracy of the references. The Journal complies with the reference style given in "Uniform Requirements for Manuscripts Submitted to Biomedical Journals" (available from The New England Journal of Medicine, Bulk Reprints, 1440 Main Street, Waltham, MA 02154, U.S.A.; send self-addressed stamped envelope). References are to be cited in numerical order in text and identified by Arabic numerals set in superscript type. Authors will be charged $\$ 3.00$ for each reference over 15 . The reference section should be typed double-spaced at the end of the text, following the sample formats given below. For abbreviations of journal names, refer to List of Journals Indexed in Index Medicus (available from the Superintendent of Documents, U.S. Government Printing Office, Washington, DC 20402, U.S.A.; DHEW Publication No. (NIH) 91-267; ISSN 0093-3821).

Provide all authors' names when fewer than seven; when seven or more, list the first three and add et al. Provide article titles and inclusive pages. "Unpublished observations" and "personal communications" do not qualify as references and should be placed parenthetically in the text. Accuracy of reference data is the responsibility of the author.

Sample references are given below:

Journal article

1. Rand NS, Dawson JM, Juliao SF, et al. In vivo macrophase recruitment by murine intervertebral disc cells. J Spinal Disord 2001; 14:339-342.

\section{Book chapter}

2. Todd VR. Visual information analysis: frame of reference for visual perception. In: Kramer P, Hinojosa J, eds. Frames of Reference for Pediatric Occupational Therapy. Philadelphia, PA: Lippincott Williams \& Wilkins; 1999:205-256.

\section{Entire book}

3. Webster NR, Galley HF. Anaesthesia Science. Oxford, UK: Blackwell Publishing, Ltd.; 2006.

\section{Software}

4. Epi Info [computer program]. Version 6. Atlanta, GA: Centers for Disease Control and Prevention; 1994.

Online journals

5. Friedman SA. Preeclampsia: a review of the role of prostaglandins. Obstet Gynecol [serial online]. January 1988;71:22-37. Available from: BRS Information Technologies, McLean, VA. Accessed December 15, 1990.

\section{Database}

6. CANCERNET-PDQ [database online]. Bethesda, MD: National Cancer Institute; 1996.

Updated March 29, 1996. 
7. Gostin LO. Drug use and HIVIAIDS [JAMA HIVIAIDS Web site]. June 1, 1996. Available at: http://www.ama-assn.org/special/hiv/ethics. Accessed June 26, 1997.

\section{Figures}

Each figure must be identified individually (e.g., Figure 1, Figure 2, etc.) and within the text of the manuscript. Authors may either type the label in the "Caption/Legend" box or add a text box onto each figure. Black and white illustrations will be published without charge. Authors will be charged for color illustrations in print. Color illustrations online are free of charge. The Publisher will provide, upon request, an estimate of the cost of color artwork.

a. All figures must be submitted as a separate attachment. Do not insert figures into the main document.

b. "Attached Figures" must be identified within the "Text Portion" of the paper. c. The "Attached Figures" must be labeled (e.g., Figure 1, Figure 2, etc). Authors may either type the label in the "Caption/Legend" box or add a text box onto each figure.

Digital art needs to be created/scanned and saved and submitted as either a TIFF (tagged image file format), an EPS (encapsulated postscript) file. PPT (Power Point) files will also be accepted. Electronic photographs-radiographs, CT scans, and so on-and scanned images must have a resolution of at least $300 \mathrm{dpi}$. Line art must have a resolution of at least 1200 dpi (dots per inch). If fonts are used in the artwork, they must be converted to paths or outlines or they must be embedded in the files. Color images must be created/scanned and saved and submitted as CMYK files. If you do not have the capability to create CMYK files, please disregard this step. Indicate in your cover letter that you are unable to produce CMYK files. Cite figures consecutively in the text, and number them in the order in which they are discussed.

\section{Digital Art Checklist:}

- Create and submit artwork in the actual size it will appear in the journal

- Crop out any extra white or black space surrounding the image

- Text within figures should be in an acceptable font (Helvetica is preferred) and sized consistently throughout the artwork using 8-12 point type

- Text within figures should be embedded in the file or converted to an outline or path

- For black and white images: create and save in grayscale format

- For color files: create and save in CMYK format (not RGB)

- For line art: save and submit at a resolution of at least $1200 \mathrm{dpi}$

- For images/photographs: save and submit at a resolution of at least $300 \mathrm{dpi}$

- For combination halftones: save and submit TIFF or EPS files. Do not select "Save as

Compressed TIFF" when saving files. PowerPoint files are also acceptable

- Save each figure as a separate file and save them separate from the accompanying text file(s). For multipanel or composite figures only: send as one files with each part labeled the way it is to appear in print

- Name figures in the format: corresponding author's last name_figure 1.tif, etc.

- Upload figures consecutively to the submission site.

Detailed Figure Instructions: Please refer to this website for detailed information on digital figure preparation, and to check your figure instantly for printer compatibility:

http://rapidinspector.cadmus.com/RapidInspector/docs/index.html 
Figure legends: Each figure must be accompanied by an explanatory legend, typewritten with double spacing (legends should be separate from the figures, but do not use a separate sheet for each legend). They should be brief and specific, and they should appear on a separate manuscript page after the references. Use scale markers in the image for electron micrographs, and indicate the type of stain used. Explain all symbols used in the figure.

Tables:Each table must be identified individually and within the text of the manuscript. Do not include the same information in both tables and figures. Create tables using the table creating and editing feature of your word processing software (e.g., Word, WordPerfect). Do not use Excel or comparable spreadsheet programs. Group all tables in a separate file. Tables should be typed neatly, each table on a separate sheet, with the title above and any notes below. Explain all abbreviations. Tables should be numbered consecutively beginning with Roman numeral I. A table must have at least two columns. Lists are to be incorporated into the text. Each table should appear on a separate page and should include the table title, appropriate column heads, and explanatory legends (including definitions of any abbreviations used). Do not embed tables within the body of the manuscript. They should be self-explanatory and should supplement, rather than duplicate, the material in the text. Do not use patient initials in tables. Patients should be referred to by sequential Arabic numerals, not by their initials.

\section{Supporting Information (Supplementary Materials):}

Authors may publish additional article-related materials online that compliments and reinforces information published in the print journal. Supplementary material posted online is intended to enhance print article content, and may include figures, tables, movies and animation.

All supplemental materials must be submitted with the original submission via Manuscript Central for peer-review and be approved by the Editor in order to be published online. Authors should reference the fact that they have supplied supplemental data with their submission in their cover letter as well as designate the files as Supplemental Files during upload.

There are no restrictions on file types of the data that you submit. Please keep in mind, however, that the more universal the file type, the more accessible to the community.

Because all supplementary materials submitted for addition online are posted exactly as provided to the Publisher, authors are advised to review materials carefully. Data will be posted as it is submitted; it will not be professionally edited or proofread. No additional work or file processing will be performed on any submission. The Publisher will not be responsible for errors or omissions.

Audio and Video Files: Short audio and video clips may be submitted for posting online as a .wav, .avi, .mov or .mpg file format. Audio and video files must be compressed to the smallest possible size that still allows for high resolution and quality presentation. The total size of all clips, along with other submitted files for any given article, should not exceed 5MB. File size limitation is intended to ensure that end-users are able to download and view files in a reasonable time frame. If files exceed the specified size limitation, they will not be posted to online and returned to the author for re-submission.

Submitting Revisions: If you have been invited to submit a revised manuscript, please submit it online via your author center following instructions found there. When submitting a revision, please submit both a clean copy and marked copy of the manuscript. The marked copy should highlight all of the changes made the by authors after the original review. Authors can use the track changes feature of the Microsoft Word program to create a 
marked copy. Authors also should submit all tables and figures in separate files for production purposes.

\section{After Acceptance}

Page proofs and corrections: Corresponding authors will receive will receive electronic page proofs to check the copyedited and typeset article before publication. Portable document format (PDF) files of the typeset pages and support documents (e.g., reprint order form) will be sent to the corresponding author by e-mail. Complete instructions will be provided with the e-mail for downloading and printing the files and for returning the corrected pages to the Publisher. It is the author's responsibility to ensure that there are no errors in the proofs. Changes that have been made to conform to journal style will stand if they do not alter the authors' meaning. Only the most critical changes to the accuracy of the content will be made. Changes that are stylistic or are a reworking of previously accepted material will be disallowed. The Publisher reserves the right to deny any changes that do not affect the accuracy of the content. Authors may be charged for alterations to the proofs beyond those required to correct errors or to answer queries. Proofs must be checked carefully and corrections returned within 24 to 48 hours of receipt, as requested in the communication accompanying the page proofs.

Reprints: Authors will receive a reprint order form and a price list with the page proofs. Reprint requests should be faxed to the publisher with the corrected proofs. Reprints are normally shipped 4 to 6 weeks after publication of the issue in which the item appears. Contact the Reprint Department: Email: reprints@wiley.com with any questions.

Publisher's Contact: Email corrected page proofs and any other related materials to Production Editor, The Laryngoscope, rsheehan@wiley.com

\section{Manuscript Checklist (before submission)}

- Title page with complete mailing address, telephone, disclosure of funding information, telefax, and e-mail of corresponding author

- Abstract in structured format and keywords

- References double-spaced in AMA style and in proper format, and numerical order in the body of the text

- Permission to reproduce copyrighted materials or signed patient consent forms

- Acknowledgments listed for grants and technical support

- Manuscript conforming to criteria listed in Instructions to Authors

- Clear indication of approval of appropriate institutional research oversight committee

Note to NIH Grantees: Pursuant to NIH mandate, Wiley-Blackwell will post the accepted version of contributions authored by NIH grant-holders to PubMed Central upon acceptance. This accepted version will be made publicly available 12 months after publication. For further information, see www.wiley.com/go/nihmandate.

\section{Pre-Submission English-Language Editing}

Authors for whom English is a second language may choose to have their manuscript professionally edited before submission to improve the English. A list of independent suppliers of editing services can be found at www.blackwellpublishing.com/bauthor/english language.asp. Japanese authors can also find a list of local English improvement services at http://www.wiley.co.jp/journals/editcontribute.html. All services are paid for and arranged by the author, and use of one of these services does not guarantee acceptance or preference for publication. 


\section{Mensagem original}

De: lynchjj@upmc.edu

Para: cwiikmann@uol.com.br

Assunto: The Laryngoscope - Manuscript number lscope-09-1480

Enviada: 14/09/2009 21:44

14-Sep-2009

Dear Dr. Wiikmann,

Your manuscript entitled "DYNAMIC VISCOSITY OF IMPLANTABLE AUTOLOGOUS MATERIALS INTO THE VOCAL FOLD" has been successfully submitted online.

Your manuscript number is lscope-09-1480. Please mention this number in all future correspondence regarding this submission.

You can view the status of your manuscript at any time by checking your Author Center after logging into http://mc.manuscriptcentral.com/lscope. If you have difficulty using this site, please click the 'Get Help Now' link at the top right corner of the site.

Thank you for submitting your manuscript to The Laryngoscope.

Sincerely,

Jackie Lynch

Senior Editorial Coordinator

The Laryngoscope

Iroquois Building, Suite 305

200 Lothrop Street

Pittsburgh, PA 15213

Telephone: 412-648-6304

Fax: 412-648-6300 
DYNAMIC VISCOSITY OF IMPLANTABLE AUTOLOGOUS MATERIALS INTO THE VOCAL FOLD

Christian Wiikmann, MD.

Marcelo Alves da Silva, PhD.

Elizabeth Pinheiro Gomes Arêas, PhD.

Rui Imamura, MD, PhD.

Domingos Hiroshi Tsuji, MD, PhD.

Luiz Ubirajara Sennes, MD, PhD.

From the Disciplina de Otorrinolaringologia da Faculdade de Medicina da Universidade de São Paulo (Wiikmann, Imamura, Tsuji, Sennes) and the Laboratório de Biofisico-Química do Instituto de Química da Universidade de São Paulo (Silva, Arêas)

Running title: Viscosity of implantable autologus materials

This paper has not had any financial support or funding

Corresponding author:

Christian Wiikmann

Rua Marquês de Olinda, 1263

08790-510 Mogi das Cruzes- SP Brazil

cwiikmann@uol.com.br

Presented at the XXXIX Congresso Brasileiro de Otorrinolaringologia e Cirurgia Cérvico-Facial, Belo Horizonte-MG Brazil, April 4th, 2008. 
ABSTRACT

OBJECTIVE: To compare the dynamic viscosity of superficial layer of temporalis fascia with that of other biological tissues traditionally used for vocal fold implants to treat vocal fold rigidity.

STUDY DESIGN: Experimental.

METHOD: Measurement of dynamic viscosity of samples of superficial layer of temporalis fascia, deep layer of temporalis fascia and abdominal fat of 12 cadavers. RESULTS: Dynamic viscosity values of the different samples were presented in the following increasing order: superficial layer of temporalis fascia, deep layer of temporalis fascia and abdominal fat. There was statistical difference between the samples.

CONCLUSION: Dynamic viscosity of superficial layer of temporalis fascia is lower than of other tissues tested.

KEY WORDS: Larynx, vocal fold, rheology, viscosity, rheometer, temporalis fascia, abdominal fat. 


\section{INTRODUCTION}

Rigidity of vocal fold mucosa may lead to poor vocal quality and represents a major challenge for laryngology. ${ }^{1}$ Surgical management tries to recover the lamina propria through grafting of biological or synthetic material so as to create a pad over

which the epithelium may easily vibrate and, thus, produce voice of better quality. ${ }^{2,3}$ The viscosity of a given material may be grossly defined as its resistance to flow. The lower the viscosity of vocal fold mucosa, the lower the subglottic pressure required to start phonation. ${ }^{4}$ Thus, the use of less viscous materials as grafts may favor postoperative outcomes.

In our country, superficial layer of temporalis fascia (SLTF) has been used to treat vocal fold rigidity, with promising results. ${ }^{5}$ The purpose of the present study was to assess dynamic viscosity of SLTF comparing it to other biological tissues traditionally used as vocal fold implants: deep layer of temporalis fascia (DLTF) and abdominal fat.

\section{MATERIAL AND METHODS}

Samples were collected from the Department of Pathology of the University of São Paulo, after approval of the Internal Research Ethics Committee. Samples from 12 cadavers (five men and seven women, aged 49 to 87 years) were collected within 18 hours after death and placed in cold saline solution (approximately $4^{\circ} \mathrm{C}$ ) for transportation.

The following fragments were removed from each cadaver: SLTF fragment (defined as fibrous tissue located between the dermis and deep temporalis fascia) measuring approximately one centimeter in diameter, and $2 \mathrm{~cm}$ posteriorly from the 
external auditory canal; fragment of DLTF (fibrous layer more organized than STF and easily differentiated from it, immediately superficial to the temporalis muscle), measuring approximately one centimeter in diameter and $2 \mathrm{~cm}$ posteriorly from the external auditory canal; and fragment of abdominal fat (superficial layer), measuring approximately one centimeter in diameter and approximately one millimeter thick, through median incision made $2 \mathrm{~cm}$ above the umbilical scar. Samples were collected and their viscosity was measured on the same day, dispensing freezing.

The parameter measured in each sample was dynamic viscosity (DV), which may be defined as measurement of internal friction of a given material during deformation and it is related with the resistance to flow of the material. DV is one of the most widely used parameters to study viscoelastic properties of biological tissues, and the one that has the greatest clinical correlation.

DV was obtained using rheometer Physica MCR 300 (Paar Physica, Stuttgart, Germany), with parallel $8 \mathrm{~mm}$-plates. We used frequency scanning of 0.01 to $2 \mathrm{~Hz}$, at $0.4 \%$ of deformation in all samples. One hundred measurements of each sample were distributed within the frequency range. The experiment was carried out at $37^{\circ} \mathrm{C}$, with precision over $0.05^{\circ} \mathrm{C}$ through a Peltier system.

Experiments were performed within the linear viscoelastic region of the sample, as defined by previous experiments of amplitude scanning that we have performed (data not shown).

The material was placed between two parallel plates of the rheometer, and the lower plate was fixed whereas the upper one was mobile and connected to the device central axis. The mobile plate received a torsion force controlled by sinusoidal oscillation method that controlled the conditions of amplitude and frequency of 
applied sinusoidal wave. The response of the material to the applied deformation was measured and provided the dynamic viscosity of the material.

Tissue samples were placed so that the whole area of the mobile plate would be in contact with the tissue, an essential condition for the comparison between the samples. We placed mineral oil on the rims of the measurement plates to avoid drying of the sample, which could have led to increase in DV. The gap between the parallel plates was defined by the compression to which the sample was submitted $(0.5 \mathrm{~N})$ and was controlled by the rheometer.

To compare the results of DV between the different tissues, we used the analysis of variance (ANOVA) with repeated measurements. The significance level we adopted was $5 \%$.

\section{RESULTS}

We performed about one hundred measurements in each sample. Table I shows mean DV for each type of tissue within specific frequency intervals. Graphic representations of mean DV curves for each type of tissue in specific frequency intervals are shown in Figure 1.

The DV of the different samples in increasing order was: SLTF, DLTF and abdominal fat. Multiple comparisons, regardless of the frequency intervals, indicated that the difference in DV between the samples was statistically significant (Table II).

\section{DISCUSSION}

There is a great variety of materials that can be used for injections and implants in the vocal folds. Many factors may be considered when we choose a 
material: ${ }^{6,7}$ technical facility to use the material, low risk of immunogenicity, low probability of poor positioning, low absorption of material throughout time, low cost, and above all, having the material of a certain quality, which enables good mobility of the epithelium, which ultimately depends on DV.

Thus, low viscosity materials are desirable. Therefore SLTF, which has lower viscosity than other traditionally used autologous tissues for vocal fold implant, may be a promising material to be used in this type of procedure. Moreover, as it may be obtained from the patient, STF does not have the risk of causing foreign body reactions or immunomediated reactions, it has low cost it is and easy to be obtained.

DV has a decreasing function with frequency in all samples, almost linearly to a logarithmic scale (Figure 1). This type of response has been obtained in other studies that measured viscoelastic properties of biological materials.

The use of gap between the parallel plates controlled by compression of sample represents an innovation in rheometer studies related with implantable materials in laryngology. In articles reviewed by the authors, fixed gaps were used. However, biological tissue samples have heterogeneous thickness. The use of the same gap to different samples could result in different levels of compression made by the plates over the samples. A previous study carried out by the authors with vocal folds showed that the same sample, when submitted to different compression levels, may have different DV measurements. ${ }^{8}$ Thus, we decided to use gap between the plates defined by compression of $0.5 \mathrm{~N}$. This levels of compression was chosen because it was the lower compression that allowed acceptable contact of the sample to the plates and produced regular patterns of response. Nevertheless, we do not 
know what is the compression level to which a vocal fold implant is submitted in clinical conditions.

In the present study, we used fresh tissue samples collected within 18 hours after death, and avoided modifications that could have been caused by freezing. ${ }^{9}$

As we can see in Figure 1, DV is a function of oscillation frequency. In this study, we used frequency scanning between 0.01 and $2 \mathrm{~Hz}$, which is a smaller range than regular vocal mucosa vibration during human phonation (150-250 Hz). However, this is a limitation of the used method. As of $3 \mathrm{~Hz}$, inertial effects ${ }^{7}$ and wall-slipping $^{10}$ become significant, and the validity of obtained data may be questioned. In our study, this phenomenon occurred in lower frequencies than in similar studies ${ }^{7}$, in which inertia became significant as of $15 \mathrm{~Hz}$, possibly because we used smaller diameter plates. ${ }^{11,12}$ However, the literature has shown that low frequency data obtained from vocal fold rheological studies may be extrapolated to phonation frequencies. $^{10,13,14}$

The comparison of values of viscosity measured in this study with other studies previously performed is hindered by the methodological difference (the present study used gap between the parallel plates controlled by compression as opposed to the use of fixed gap in others), as already mentioned.

The use of SLTF as laryngeal implantable material is a promising technique, taking into account the low DV of the material when compared to other traditionally used tissues for these procedures. Further clinical and experimental studies should be performed to assess other parameters such as facility of use, reabsorption potential and vocal quality outcomes. 


\section{CONCLUSION}

Superficial layer of temporalis fascia presents lower dynamic viscosity than that of deep layer of temporalis fascia and abdominal fat. 


\section{REFERENCES}

1- Thibeault SL, Gray SD, Bless DM, Chan RW, Ford CN. Histologic and rheologic characterization of vocal fold scarring. J Voice 2002;16:96-104.

2- Tsunoda K, Takanosawa M, Niimi S. Autologus transplantation of fascia into the vocal fold: a new phonosurgical technique for glottal incompetence. Laryngoscope 1999;109:504-508.

3- Damrose EJ, Berke GS. Advances in the management of glottic insufficiency. Curr Opin Otolaryngol Head Neck Surg 2003;11:480-484.

4- Titze IR. The physics of small-amplitude oscillation of the vocal folds. J Acoust Soc Am 1988;83:1536-1552.

5- Costa JO, Gama ACC, Oliveira JB, Rezende Neto AL. Acoustic analysis and perceptual ratings of voice before and after surgery for implantation of prefascia temporal muscle. Rev CEFAC São Paulo 2008;10:76-83.

6- Chan RW, Titze IR. Viscosities of implantable biomaterials in vocal fold augmentation surgery. Laryngoscope 1998;108:725-731.

7- Hertegard S, Dahlqvist A, Laurent C, Borzacchiello A, Ambrosio L. Viscoelastic properties of rabbit vocal folds after augmentation. Otolaryngol Head Neck Surg 2003;128:401-406.

8- Wiikmann C, Silva MA, Areas EPG, Tsuji DH, Sennes LU. Measurement of viscoelastic properties of vocal folds. Ann Otol Rhinol Laryngol 2009;118:461464.

9- Chan RW, Titze IR. Effect of postmortem changes and freezing on the viscoelastic properties of vocal fold tissues. Ann Biom Eng 2003;31:482-491. 
10- Chan RW, Titze IR. Viscoelastic shear properties of human vocal fold mucosa: theoretical characterization based on constitutive modeling. J Acoust Soc Am 2000;107:565-580.

11- Chan RW, Titze IR. Viscoelastic shear properties of human vocal fold mucosa: measurement methodology and empirical results. J Acoust Soc Am 1999;106:2008-2020.

12- Titze IR, Klemuk SA, Gray S. Methodology for rheological testing of engineered biomaterials at low audio frequencies. J Acoust Soc Am 2004;115:392-401.

13- Chan RW. Estimation of viscoelastic shear properties of vocal fold tissues based on time-temperature superposition. J Acoust Soc Am 2001;110:1548-1561.

14- Chan RW. Measurements of vocal fold tissue viscoelasticity: approaching the male phonatory frequency range. J Acoust Soc Am 2004;115:3161-3170. 


\begin{tabular}{|c|c|c|c|c|c|c|}
\hline $\begin{array}{l}\text { Frequency } \\
\text { range } \\
(\mathrm{Hz})\end{array}$ & $\begin{array}{c}\text { SLTF } \\
\text { M } \\
\text { (Pa.s) }\end{array}$ & $\begin{array}{c}\text { SLTF } \\
\text { SD } \\
\text { (Pa.s) }\end{array}$ & $\begin{array}{c}\text { DLTF } \\
\text { M } \\
\text { (Pa.s) }\end{array}$ & $\begin{array}{c}\text { DLTF } \\
\text { SD } \\
\text { (Pa.s) }\end{array}$ & $\begin{array}{c}\text { FAT } \\
\text { M } \\
\text { (Pa.s) }\end{array}$ & $\begin{array}{c}\text { FAT } \\
\text { SD } \\
\text { (Pa.s) }\end{array}$ \\
\hline $0.01-0.02$ & 59.355 & 21.825 & 141.146 & 62.475 & 287.129 & 111.451 \\
\hline$>0.02-0.03$ & 31.134 & 14.457 & 77.548 & 33.330 & 164.032 & 64.538 \\
\hline$>0.03-0.04$ & 19.224 & 7.9 & 54.276 & 20.92 & 117.544 & 41.053 \\
\hline$>0.04-0.05$ & 14.998 & 7.958 & 41.333 & 16.49 & 79.112 & 31.607 \\
\hline$>0.05-0.06$ & 11.335 & 5.278 & 30.73 & 9.237 & 60.813 & 20.576 \\
\hline$>0.06-0.07$ & 11.124 & 5.247 & 29.893 & 20.954 & 48.567 & 16.49 \\
\hline$>0.07-0.08$ & 9.667 & 4.373 & 28.87 & 18.118 & 39.739 & 12.178 \\
\hline$>0.08-0.09$ & 8.297 & 4.441 & 21.021 & 10.611 & 35.704 & 15.716 \\
\hline$>0.09-0.1$ & 6.820 & 3.9 & 14.912 & 5.688 & 27.888 & 11.211 \\
\hline$>0.1-0.2$ & 4.775 & 2.418 & 14.065 & 6.249 & 20.591 & 6.324 \\
\hline$>0.2-0.3$ & 3.246 & 1.587 & 8.242 & 3.533 & 11.568 & 4.367 \\
\hline$>0.3-0.4$ & 2.743 & 1.114 & 6.939 & 2.846 & 8.067 & 2.58 \\
\hline$>0.4-0.5$ & 1.984 & 0.93 & 5.677 & 2.635 & 6.861 & 2.404 \\
\hline$>0.5-0.6$ & 1.829 & 0.637 & 4.315 & 1.498 & 6.006 & 1.639 \\
\hline$>0.6-0.7$ & 1.729 & 0.405 & 4.021 & 1.638 & 5.307 & 1.553 \\
\hline$>0.7-0.8$ & 1.624 & 0.530 & 3.699 & 1.625 & 4.481 & 1.341 \\
\hline$>0.8-0.9$ & 1.524 & 0.521 & 3.25 & 1.655 & 4.107 & 1.364 \\
\hline$>0.9-1$ & 1.364 & 0.436 & 3.117 & 1.414 & 3.678 & 0.9 \\
\hline$>1-2$ & 1.220 & 0.300 & 2.517 & 0.092 & 2.914 & 0.688 \\
\hline
\end{tabular}

Table I: Mean dynamic viscosity of each type of tissue when considered within each frequency range (12 samples). SLTF = Superficial Layer of Temporalis Fascia; DLTF = Deep Layer of Temporalis Fascia; FAT = Abdominal Fat; $\mathrm{M}=$ Mean; SD = Standard Deviation. 


\begin{tabular}{ll}
\hline Comparison & $\mathbf{p}$ \\
\hline SLTF X DLTF & 0.0025 \\
SLTF X FAT & $<0.0001$ \\
DLTF X FAT & 0.0006 \\
\hline
\end{tabular}

Table II: Results of the statistical analysis of multiple comparisons between dynamic viscosity of different tissues, regardless of frequency interval. SLTF $=$ Superficial Layer of Temporalis Fascia; DLTF = Deep Layer of Temporalis Fascia; FAT = Abdominal Fat; $p=$ p-value 


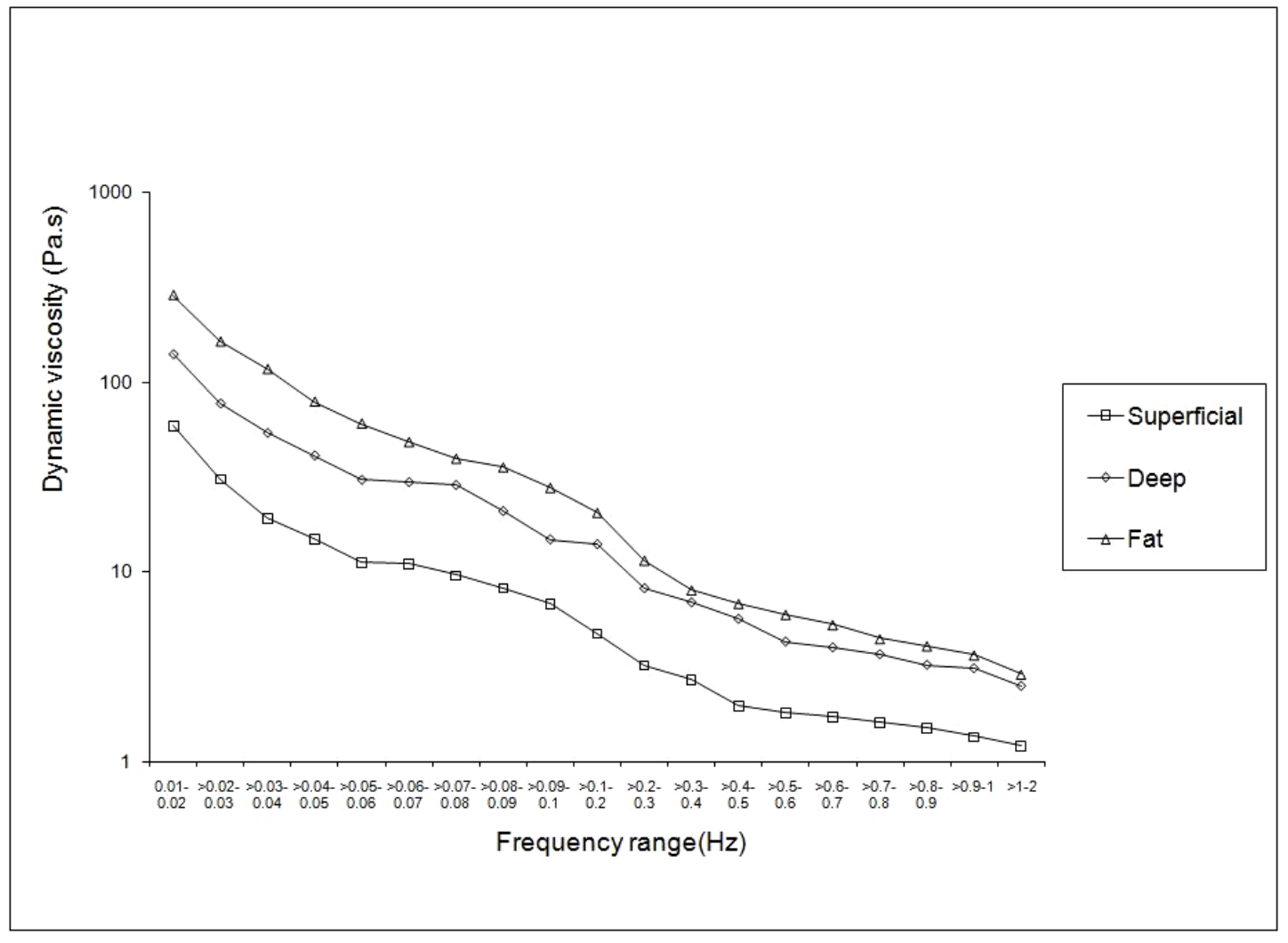

Figure 1: Mean dynamic viscosity (DV) curve for each type of tissue, when considered within the frequency range. Each spot represents mean DV of 12 samples along a given frequency interval. The axis of dynamic viscosity is shown in logarithmic scale. 
INTRODUÇÃO 
A rigidez da mucosa das pregas vocais causa o comprometimento de sua vibração e leva a uma qualidade vocal pobre; assim, representa um grande desafio na área da laringologia (Thibeault et al., 2002). Incide geralmente em decorrência de cicatrização desfavorável após cirurgias e traumas, e em associação com alterações estruturais mínimas de cobertura (cistos, sulcos, bolsas).

A rigidez da mucosa vocal geralmente denota uma alteração da lâmina própria (espaço de Reinke) ou mesmo aderência do epitélio vocal ao ligamento vocal (Tsunoda et al., 1999). O tratamento cirúrgico tenta recuperar a lâmina própria, com enxerto de materiais biológicos ou sintéticos de modo a "criar um coxim” sobre o qual o epitélio possa vibrar facilmente e, desta maneira, produzir uma voz de melhor qualidade (Tsunoda et al., 1999; Damrose, Berke, 2003).

Diversos materiais têm sido utilizados como enxertos, desde materiais biológicos autólogos como gordura abdominal (Brandenburg et al., 1996), fáscia temporal (Tsunoda et al., 1999), fáscia lata (Rhikanen, 1998) e, combinações das anteriores (Hsiung et al., 2004), até materiais sintéticos como teflon (Tsunoda et al. (1999), colágeno (Damrose, Berke, 2003) e diferentes materiais derivados do ácido hialurônico (Hertegard et al., 2002).

Quanto menor for a viscosidade de um material, menor será sua resistência ao fluir. Quanto mais baixa for a viscosidade da mucosa da prega vocal, menor deverá 
ser a pressão subglótica necessária para dar início à fonação (Titze, 1988). Desse modo, quanto mais baixa for a viscosidade de um material, mais adequado para ser implantado em prega vocal. Assim, as propriedades viscoelásticas de diversos materiais implantáveis em pregas vocais sejam biológicos (Chan, Titze, 1998) ou sintéticos (Chan, Titze, 1998, 1999; Kriesel,2002; Hertegard et al., 2003; Dahlqvist et al., 2004; Klemuk, Titze, 2004; Hansen et al., 2005) vêm sendo estudados.

Recentemente a camada superficial da fáscia temporal (CSFT) tem sido utilizada em implantes de pregas vocais para o tratamento de rigidez de prega vocal, mostrando resultados promissores (Costa et al., 2008). 
2 OBJETIVO DO ESTUDO 
O objetivo deste estudo é avaliar a viscosidade dinâmica da CSFT em comparação com outros tecidos biológicos tradicionalmente utilizados em implantes de pregas vocais: camada profunda da fáscia temporal (CPFT) e gordura abdominal. 
3 REVISÃO DE LITERATURA 
Finkelhor et al., em 1987, demonstram, em laringes excisadas, que pregas vocais mais hidratadas (com viscosidade mais baixa) apresentam maior amplitude oscilatória.

Titze, em 1988, demonstra analiticamente que a pressão de limiar fonatório, definida como a pressão subglótica mínima necessária para produzir oscilação de prega vocal, varia diretamente com a viscosidade da mucosa da prega vocal.

Desde então, vários estudos que permitem avaliar propriedades viscoelásticas de pregas vocais e de materiais implantáveis em pregas vocais são realizados.

\subsection{Estudos de viscosidade de pregas vocais normais}

Chan e Titze, em 1999, estudam propriedades reológicas de 15 amostras de mucosa de pregas vocais de cadáveres. Utilizam reômetro de placas paralelas com 20mm de diâmetro e com espaçamento fixo de $0,3 \mathrm{~mm} ; 0,25 \mathrm{~mm}$ ou $0,2 \mathrm{~mm}$, arbitrariamente. Observam estabilidade no módulo elástico. Ressaltam diferenças de até uma ordem de grandeza entre as diferentes amostras, atribuindo-as às diferenças entre idade e sexo. Neste estudo os autores não apresentam tratamento estatístico. 
Chan et al., em 2001, estudam a influência do ácido hialurônico nas propriedades biomecânicas da mucosa de pregas vocais. Comparam a viscosidade dessa mucosa antes e depois do tratamento com hialuronidase. Não descrevem detalhadamente o método. Observam que a viscosidade aumenta em 70\% em mucosa de pregas vocais após o tratamento com hialuronidase, inclusive com diferença estatisticamente significante. Sugerem que o ácido hialurônico possui papel fundamental na biomecânica da mucosa de prega vocal.

\subsection{Estudos de viscosidade de pregas vocais alteradas}

Chan e Tayama, em 2002, estudam propriedades biomecânicas da mucosa de pregas vocais de cães submetidas a diferentes graus de hidratação. As amostras são imersas, sequencialmente, em solução de Krebs-Ringer (isotônica), sucrose a 25\% (hipertônica-desidratação) e água destilada (hipotônica - reidratação). Medições reológicas são feitas com reômetro de placas paralelas com 20mm de diâmetro e espaçamentos variáveis $(0,3 \mathrm{~mm}$ para isotônica; $0,2 \mathrm{~mm}$ para hipertônica e $0,25 \mathrm{~mm}$ para hipotônica). Observam que a viscosidade das amostras em solução hipertônica foi maior, seguida da viscosidade das amostras em solução hipotônica e das amostras em solução isotônica. Postulam que a reidratação não ocorreu de forma completa após o tratamento com a solução hipotônica.

Thibeault et al., em 2002, estudam o efeito da cicatrização em propriedades 
biomecânicas da mucosa de pregas vocais de coelhos. Realizam biópsia de prega vocal direita (sem especificar a profundidade), deixando a prega vocal esquerda intacta. Sacrificam os animais com 60 dias de pós-operatório. Comparam a viscosidade da mucosa de pregas vocais operadas com a viscosidade das não operadas. Usam reômetro de placas paralelas com 20mm de diâmetro com espaçamento de $0,2 \mathrm{~mm}$. Observam que pregas vocais operadas apresentam viscosidade mais alta que as não operadas, com diferença estatisticamente significante.

Kriesel et al., em 2002, estudam efeito da injeção de colágeno na viscosidade de pregas vocais previamente lesadas. Realizam lesão em ambas as pregas vocais de 20 coelhos. Após 10 semanas, realizam injeção de colágeno em uma das pregas em 10 amimais e de soro fisiológico em uma das pregas de outros 10 animais. Coletam a mucosa das pregas vocais após 10 semanas. Usam reômetro de placas paralelas sem citar o tamanho do diâmetro e com espaçamento de 0,3mm. Comparam a viscosidade da mucosa de pregas vocais de animais dos grupos seguintes: injeção de colágeno; injeção de soro fisiológico; e, não injetada. Observam grande variabilidade entre amostras e não observam diferença estatisticamente significante em relação à viscosidade. Sugerem que o colágeno seja melhor para medializar do que para restaurar propriedades viscoelásticas de mucosa vocal.

Rousseau et al., em 2003, avaliam a viscosidade da mucosa de pregas vocais após tratamento cirúrgico. Seis cães são submetidos à decorticação total de uma prega vocal. A outra é utilizada como controle. Três cães são sacrificados com dois meses de pós-operatório e três são sacrificados com seis meses de pós-operatório. Somente a metade posterior de cada prega vocal é utilizada para medições 
reológicas. Utilizam reômetro de placas paralelas com 7,9mm de diâmetro e $1 \mathrm{~mm}$ de espaçamento, com alcance de freqüência de 0,016Hz a 48Hz. Encontram tendência a aumento da viscosidade nas amostras de pregas operadas, mas sem obter diferença estatisticamente significante entre os grupos.

Hansen et al., em 2005, estudam a viscosidade de pregas vocais submetidas a injeção com compostos de ácido hialurônico imediatamente após a lesão da prega vocal de coelhos. Provocam lesão (não especificada) em ambas as pregas vocais: uma é injetada com ácido hialurônico no sítio da lesão; e, a outra é injetada com soro fisiológico. As medições reológicas são realizadas três semanas após a cirurgia. É utilizado reômetro de placas paralelas com 30mm de diâmetro e espaçamento controlado por pressão (embora sem especificar qual grandeza). Observam que as pregas vocais tratadas com compostos de ácido hialurônico apresentam viscosidades mais baixas, com diferença estatisticamente significante.

Hertegard et al., em 2006, avaliam efeito de injeção de células tronco mesenquimais humanas (CTMH) em cicatrização de pregas vocais. Provocam lesão em pregas vocais e injetam CTMH ou solução fisiológica no sítio da lesão. Utilizam pregas vocais não lesadas como controle. Após quatro semanas, realizam medições reológicas na mucosa das pregas vocais (com porções de músculo tireoaritenóide) de coelhos, com reômetro de placas paralelas de $8 \mathrm{~mm}$ de diâmetro, com espaçamento de 0,5mm. Observam que ambos os grupos de pregas vocais operadas apresentaram-se com viscosidade mais alta que o grupo controle, com diferença estatisticamente significante. O grupo tratado com CTMH apresenta viscosidade mais baixa que o grupo injetado com solução fisiológica, mas sem diferença estatisticamente significante. 
Cedervall et al., em 2007, avaliam efeito de injeção de células tronco embrionárias (CTE) humanas em cicatrização de pregas vocais de coelhos. Provocam lesão em pregas vocais e injetam CTE ou solução fisiológica no sítio da lesão. Utilizam pregas vocais não lesadas como controle. Após quatro semanas, realizam medições reológicas na mucosa das pregas vocais (com porções de músculo tireoaritenóide), com reômetro de placas paralelas de $8 \mathrm{~mm}$ de diâmetro, com espaçamento de 0,5mm. Observam que o fato de a amostra não preencher toda a superfície da placa poderia gerar imprecisões no valor absoluto das medições. Observam que o grupo tratado com CTE apresenta viscosidade mais baixa que o grupo injetado com solução fisiológica, com diferença estatisticamente significante.

\subsection{Viscosidade de materiais implantáveis em pregas vocais}

Chan e Titze, em 1998, utilizam o reômetro de placas paralelas para comparar a viscosidade de diversos materiais implantáveis (teflon, colágeno - 0,0075\% GAX e Zyderm, suspensão de Gelfoam, gordura abdominal - processada sem tecido fibroso) em pregas vocais, e utilizam a mucosa vocal de cadáveres como controle. Utilizam placa paralela de $20 \mathrm{~mm}$ de diâmetro, com espaçamento fixo de $0,3 \mathrm{~mm}$ e intervalo de freqüência de $0,01 \mathrm{~Hz}$ a $15 \mathrm{~Hz}$. A ordem crescente do valor da viscosidades é: prega vocais, gordura abdominal, colágeno implantável, gelfoam e teflon. Não é utilizado método de comparação estatístico. Os autores sugerem que, por meio do parâmetro 
viscosidade, a gordura abdominal pode ser considerada mais adequada para implantação em pregas vocais.

Chan e Titze, em 1999, estudam propriedades reológicas de soluções de ácido hialurônico em várias concentrações. Utilizam reômetro de placas paralelas com 20mm de diâmetro e 0,3mm de espaçamento. Os autores comparam os resultados alcançados com controles históricos de teflon, gelfoam, colágenos injetáveis, gordura abdominal e mucosa de pregas vocais de cadáveres. Não apresentam comparação estatística. Observam que as soluções de ácido hialurônico apresentam viscosidade mais baixa, inclusive que as mucosas vocais. Sugerem que, do ponto de visto da biomecânica, são materiais mais indicados para implantação em pregas vocais.

Hertegard et al., em 2003, estudam viscosidade de pregas vocais de coelhos que receberam injeção de ácido hialurônico, colágeno e teflon comparadas as pregas não injetadas. Sacrificam os animais logo após o procedimento. Usam reômetro de placas paralelas com placa de $15 \mathrm{~mm}$ de diâmetro e espaçamento de $0,5 \mathrm{~mm}$. Dissecam parte do músculo tireoaritenóide junto com a mucosa vocal. Observam que a viscosidade das pregas injetadas com ácido hilurônico apresenta-se bem próxima à viscosidade das pregas vocais não injetadas. A viscosidade da pregas vocais injetadas com colágeno e teflon apresenta-se mais elevada em relação à das pregas não injetadas, e a viscosidade mais elevada é observada nas pregas injetadas com teflon. Não apresentam tratamento estatístico dos resultados.

Klemuk e Titze, em 2004, comparam propriedades viscoelásticas de três materiais implantáveis em pregas vocais: Zyderm II, composto de colágeno, e Cymetra, gel de ácido hialurônico. Utilizam o reômetro de placas paralelas de 30mm 
de diâmetro e espaçamento de 0,2mm. Observam que a viscosidade do gel de ácido hialurônico é mais baixa que a dos compostos de colágeno.

Dalhqvist et al., em 2004, comparam a viscosidade de pregas vocais de coelhos (incluindo o músculo TA) injetadas com diferentes compostos, seis meses após a injeção. Utilizam compostos de ácido hialurônico (hylan B gel e dextranomeros em hialunonan-DHIA), colágeno e teflon. Utilizam o reômetro de placas paralelas de $15 \mathrm{~mm}$ de diâmetro, mas não especificam o espaçamento. Observam que a viscosidade das pregas injetadas com compostos de ácido hialurônico apresenta viscosidade próxima a de pregas vocais não injetadas. Pregas injetadas com teflon apresentam as viscosidades mais altas, seguidas aquelas injetadas com colágeno. Não foi apresentada a análise estatística dos resultados. O padrão da diferença da viscosidade entre os materiais injetáveis, quando as medições são feitas após a injeção, segue o mesmo padrão das diferenças no valor da viscosidade quando as medições são feitas diretamente nas substâncias injetáveis.

Caton et al., em 2007, comparam a viscosidade de cinco materiais comumente utilizados em injeção nas pregas vocais: Cymetra (derivado de colágeno), Radiesse (derivado de hidroxiapatita), Restilane, Hylaform e CarbylanGSX 5\%. Os últimos três são compostos de ácido hialurônico. Utilizam o reômetro de placas paralelas com 45mm de diâmetro e 0,25mm de espaçamento. Observam que ó valor da viscosidade é crescente para os materiais injetados nessa ordem: Carbylan-GSX 5\%, Hylaform, Restilane, Radiesse e Cymetra. Não apresentam análise estatística. 


\subsection{Sobre o método de medição de propriedades viscoelásticas em pregas vocais e materiais implantáveis}

Uma das críticas sobre as medições das propriedades reológicas de pregas vocais e de materiais implantáveis em laringe é que tais medições são comumente realizadas numa faixa de freqüências muito inferior (tipicamente $0,01-15 \mathrm{~Hz}$ ) àquela frequência fonatória habitual $(>100 \mathrm{~Hz})$. Chan e Titze, em 2000, estudam a possibilidade de extrapolação de dados obtidos para freqüências baixas e para freqüências mais altas, baseados em duas teorias viscoelásticas matemáticas descritas no trabalho dos autores. Tais teorias são aplicadas a dados históricos sobre as propriedades viscoelásticas das pregas vocais. Os resultados mostram que as predições teóricas com os dois métodos combinam razoavelmente com os dados empíricos previamente obtidos, e permitem a descrição paramétrica desses dados e sua extrapolação para freqüências de fonação. Reconhecem que esse estudo não substitui um estudo experimental na escala de freqüência da fonação, que necessita de avanços tecnológicos em reometria.

Chan, em 2001, estuda a possibilidade de extrapolação de dados adquiridos em freqüências baixas para freqüências mais altas e utiliza o método de sobreposição tempo-temperatura. A STT é uma abordagem híbrida teórico-empírica comumente utilizada por reologistas para estimar as propriedades viscoelásticas de sistemas poliméricos em escalas de freqüência não acessíveis experimentalmente. Apóia-se na observação de que para muitos polímeros, as mudanças na configuração molecular que ocorrem em determinada escala de freqüência, em temperatura baixa, correspondem àquelas que ocorrem numa escala de freqüência menor em 
temperatura alta. Avalia a viscosidade de pregas vocais em diversas temperaturas. Observa que a viscosidade de pregas vocais em temperaturas baixas e em freqüências baixas era equivalente à viscosidade de pregas vocais a $37^{0} \mathrm{C}$ em freqüências mais altas. A partir daí, calcula como seria a viscosidade de pregas vocais em freqüências de fonação. Contudo, observa a limitação do método, visto que a mucosa da prega vocal não pode ser considerada um sistema polimérico simples. Reconhece que este estudo não substitui um estudo experimental na escala de freqüência da fonação, e que são necessários avanços tecnológicos em reometria.

Chan e Titze, em 2003, comparam a viscosidade da mucosa de pregas vocais de cães imediatamente após o sacrifício, 24 horas após o sacrifício, em solução salina em temperatura ambiente, e após 30 dias de congelamento, tanto com congelamento rápido (nitrogênio líquido) quanto com congelamento lento (diretamente no congelador). Os autores não especificam o método de medição. Não observam diferença estatisticamente significante nas medições da viscosidade entre a amostra fresca imersa em solução salina em temperatura ambiente por 24 horas e aquela sob congelamento rápido. Observam que a viscosidade é mais alta nas amostras submetidas a congelamento lento, e uma diferença estatisticamente significante.

Chan, em 2004, avalia as propriedades viscoelásticas de mucosa de pregas vocais de cães. Utiliza o reômetro especialmente preparado para controlar erros inerciais próprios de reometria de tecidos, o que permite realizar experimentos com faixas de freqüência até $50 \mathrm{~Hz}$. Utiliza o reômetro de placas paralelas com $7,9 \mathrm{~mm}$ de diâmetro e espaçamento de $1 \mathrm{~mm}$. Compara os resultados com os dados prévios de extrapolação (Chan e Titze, 2000; Chan 2001) em experimentos realizados com freqüências baixas (até 15Hz). Os dados são bastante similares em ambos os 
experimentos, e sugerem que os valores obtidos com reometria em freqüências baixas podem ser extrapolados para freqüências de fonação $(>100 \mathrm{~Hz})$. 
4 MATERIAIS E MÉTODOS 


\subsection{Obtenção das amostras}

Foram obtidas amostras de cadáveres do Serviço de Verificação de Óbitos da Capital, após aprovação do estudo na Comissão de Ética do Hospital das Clínicas da Faculdade de Medicina da Universidade de São Paulo, HC-FMUSP (Apêndice)

Foram removidas as seguintes amostras de 12 cadáveres (cinco masculinos e sete femininos, com idades entre 49 e 87 anos) até 18 horas post mortem e colocadas em soro fisiológico frio (cerca de $4^{0} \mathrm{C}$ ) para transporte:

- Fragmento de CSFT, de aproximadamente $1 \mathrm{~cm}$ de diâmetro, a aproximadamente 2cm do conduto auditivo externo (CAE);

- Fragmento de CPFT, de aproximadamente $1 \mathrm{~cm}$ de diâmetro, a aproximadamente 2cm do CAE;

- Fragmento de gordura abdominal (camada superficial), de aproximadamente $1 \mathrm{~cm}$ de diâmetro e aproximadamente $1 \mathrm{~mm}$ de espessura, por meio de incisão mediana, a aproximadamente 2cm acima da cicatriz umbilical.

Os três diferentes tipos de amostras de tecido foram removidos de cada cadáver e tiveram as viscosidades medidas no mesmo dia, não havendo necessidade de congelá-las. 


\subsection{Medições da viscosidade dinâmica (VD)}

O parâmetro medido foi a viscosidade dinâmica (VD), que pode ser definida como a medida da fricção interna de um material durante deformação sinusoidal e está relacionada com a resistência de determinado material ao fluir. A VD é um dos parâmetros mais utilizados em estudos de propriedades viscoelásticas de biotecidos e é medida em pascal por segundo (Pa.s) .

A VD foi medida com no reômetro Paar-Physica MCR 300 (Paar Physica, Stuttgart, Alemanha), Figura 1, com placas paralelas de oito milímetros de diâmetro, Figura 2.



Figura 1 - Reômetro Paar-Physica MCR 300 (Paar Physica, Stuttgart, Alemanha) 

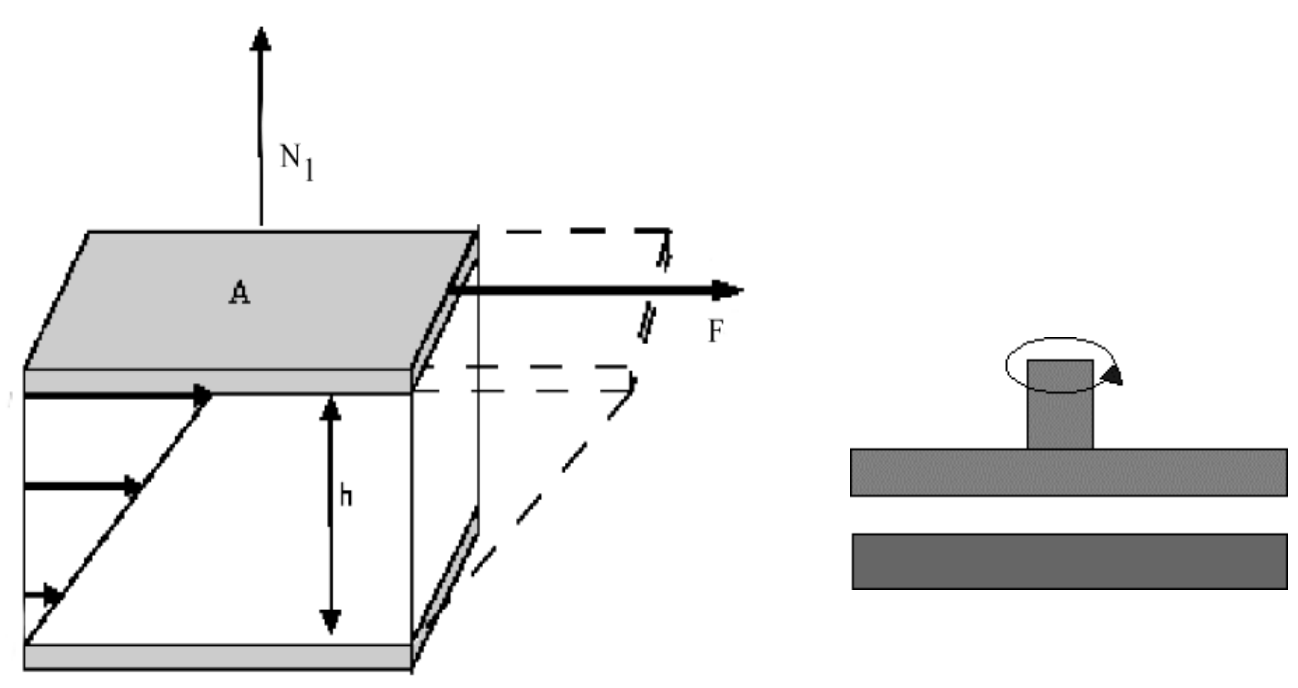

Figura 2 - Representação esquemática das placas paralelas, cujos parâmetros indicativos principais são: $\mathrm{F}$ = força torcional aplicada sobre a área da placa (A); h = espaçamento entre placas; $\mathrm{N}_{1}=$ força normal.

Os dados foram registrados por meio do software conectado ao próprio do reômetro, cuja identificação é US200/32 V 2.50, no programa Windows XP Profissional.

Foram realizadas varreduras em freqüências entre $0,01 \mathrm{~Hz}$ e $2 \mathrm{~Hz}$, a $0,4 \%$ de deformação em todas as amostras. Foram feitas 100 medições para cada amostra, distribuídas em 19 faixas de freqüência: entre $0,01 \mathrm{~Hz}$ e $0,1 \mathrm{~Hz}$, em intervalos de $0,01 \mathrm{~Hz}$; entre $0,1 \mathrm{~Hz}$ e $1 \mathrm{~Hz}$, em intervalos de $0,1 \mathrm{~Hz}$; e, para valores $>1 \mathrm{~Hz}$ e de $2 \mathrm{~Hz}$.

O experimento foi realizado em temperatura de $37^{0} \mathrm{C}$, com precisão superior a $0,05^{\circ} \mathrm{C}$, de acordo com o sistema Peltier. O reômetro estava inserido em câmara com controle de temperatura. Os experimentos foram realizados dentro da região viscoelástica linear da amostra, como definido em experimentos prévios de varredura da amplitude. 
O material foi colocado entre as duas placas paralelas do reômetro. A placa inferior era fixa e a superior móvel, e conectada ao eixo do equipamento. Aplicou-se à placa móvel uma força torcional controlada por método rotacional contínuo que controla as condições de amplitude e freqüência da onda senoidal aplicada. A resistência do material à deformação aplicada foi medida, e forneceu a viscosidade dinâmica (VD) do material.

As amostras de tecido foram colocadas de maneira que toda a área da placa móvel estivesse em contato com o tecido, condição fundamental para que se pudesse realizar a comparação entre as amostras. Colocou-se óleo mineral na borda da placa de medição para evitar o ressecamento da amostra, o que poderia resultar em um aumento da VD da amostra (Figura 3A e 3B).

Realizou-se uma medição de VD para cada tipo de tecido de cada cadáver. O espaçamento entre as placas paralelas do reômetro foi definido por compressão à qual a amostra foi submetida $(0,5 \mathrm{~N})$. 


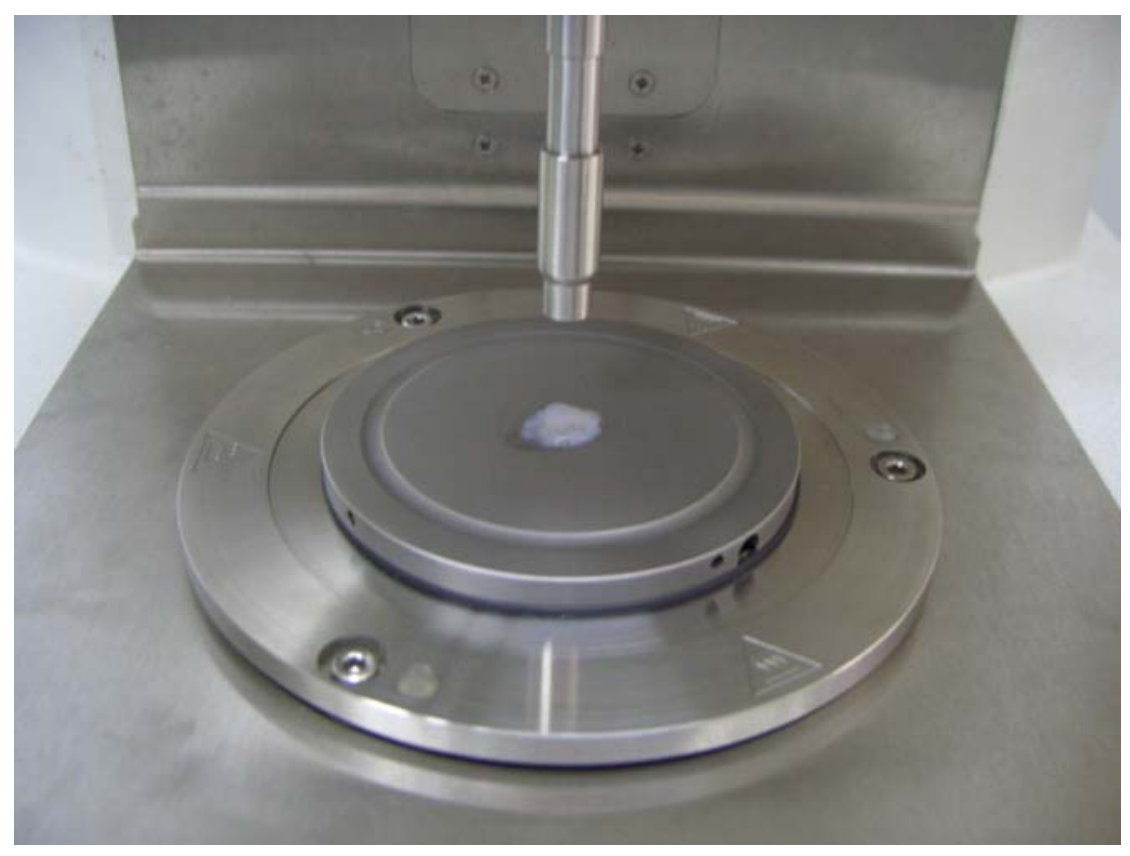

A

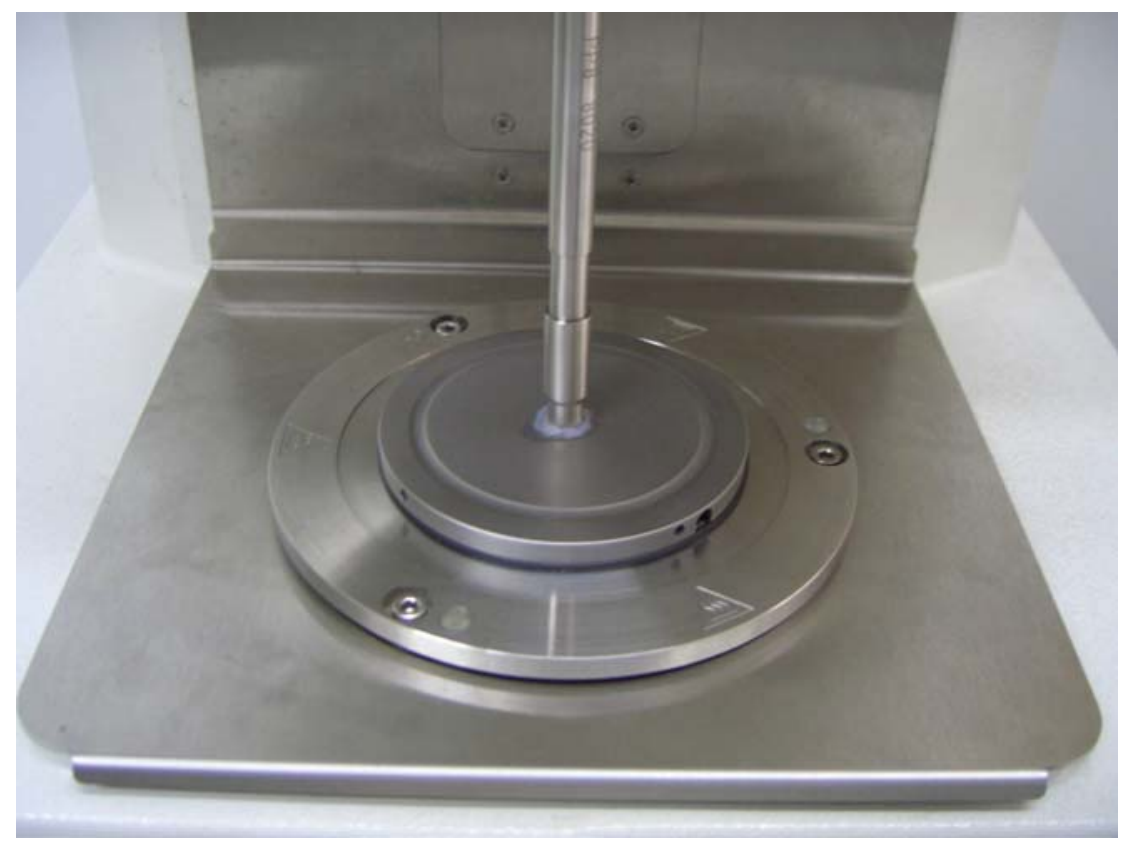

Figura 3 - Fragmento de camada superficial de fáscia temporal sobre placa fixa do reômetro. A placa móvel encontra-se suspensa (A); fragmento de camada superficial de fáscia temporal entre as placas do reômetro, ainda sem óleo mineral (B) 


\subsection{Análise estatística}

Foram obtidas 100 medições para cada amostra em diferentes faixas de frequência. Esses dados foram tabulados em uma planilha e comparados entre si.

Para comparação dos resultados da VD entre os diferentes tecidos utilizou-se o teste de análise de variâncias (ANOVA) com medidas repetidas.

O grau de significância admitido foi de 5\%. 
5 RESULTADOS 
Foram realizadas 100 medições para cada amostra. A Tabela 1 mostras os resultados das médias das medidas realizadas por faixas de freqüência consideradas.

Tabela 1 - Viscosidade dinâmica média para cada tipo de tecido para as diferentes faixas de frequência (12 amostras/faixa).

\begin{tabular}{|c|c|c|c|c|c|c|}
\hline \multirow{3}{*}{$\begin{array}{c}\text { Intervalo } \\
\text { de } \\
\text { frequências } \\
\text { (Hz) }\end{array}$} & \multicolumn{6}{|c|}{ Viscosidade dinâmica } \\
\hline & \multicolumn{2}{|c|}{ CSFT } & \multicolumn{2}{|c|}{ CPFT } & \multicolumn{2}{|c|}{ GA } \\
\hline & $\begin{array}{c}\text { Média } \\
\text { (Pa.s) }\end{array}$ & $\begin{array}{c}\text { Desvio } \\
\text { padrão } \\
\text { (Pa.s) }\end{array}$ & $\begin{array}{l}\text { Média } \\
\text { (Pa.s) }\end{array}$ & $\begin{array}{c}\text { Desvio } \\
\text { padrão } \\
\text { (Pa.s) }\end{array}$ & $\begin{array}{l}\text { Média } \\
\text { (Pa.s) }\end{array}$ & $\begin{array}{c}\text { Desvio } \\
\text { padrão } \\
\text { (Pa.s) }\end{array}$ \\
\hline $0,01-0,02$ & 59,355 & 21,825 & 141,146 & 62,475 & 287,129 & 111,451 \\
\hline$>0,02-0,03$ & 31,134 & 14,457 & 77,548 & 33,330 & 164,032 & 64,538 \\
\hline$>0,03-0,04$ & 19,224 & 7,900 & 54,276 & 20,920 & 117,544 & 41,053 \\
\hline$>0,04-0,05$ & 14,998 & 7,958 & 41,333 & 16,490 & 79,112 & 31,607 \\
\hline$>0,05-0,06$ & 11,335 & 5,278 & 30,73 & 9,237 & 60,813 & 20,576 \\
\hline$>0,06-0,07$ & 11,124 & 5,247 & 29,893 & 20,954 & 48,567 & 16,490 \\
\hline$>0,07-0,08$ & 9,667 & 4,373 & 28,870 & 18,118 & 39,739 & 12,178 \\
\hline$>0,08-0,09$ & 8,297 & 4,441 & 21,021 & 10,611 & 35,704 & 15,716 \\
\hline$>0,09-0,1$ & 6,820 & 3,900 & 14,912 & 5,688 & 27,888 & 11,211 \\
\hline$>0,1-0,2$ & 4,775 & 2,418 & 14,065 & 6,249 & 20,591 & 6,324 \\
\hline$>0,2-0,3$ & 3,246 & 1,587 & 8,242 & 3,533 & 11,568 & 4,367 \\
\hline$>0,3-0,4$ & 2,743 & 1,114 & 6,939 & 2,846 & 8,067 & 2,580 \\
\hline$>0,4-0,5$ & 1,984 & 0,930 & 5,677 & 2,635 & 6,861 & 2,404 \\
\hline$>0,5-0,6$ & 1,829 & 0,637 & 4,315 & 1,498 & 6,006 & 1,639 \\
\hline$>0,6-0,7$ & 1,729 & 0,405 & 4,021 & 1,638 & 5,307 & 1,553 \\
\hline$>0,7-0,8$ & 1,624 & 0,530 & 3,699 & 1,625 & 4,481 & 1,341 \\
\hline$>0,8-0,9$ & 1,524 & 0,521 & 3,250 & 1,655 & 4,107 & 1,364 \\
\hline$>0,9-1$ & 1,364 & 0,436 & 3,117 & 1,414 & 3,678 & 0,900 \\
\hline$>1-2$ & 1,220 & 0,300 & 2,517 & 0,092 & 2,914 & 0,688 \\
\hline
\end{tabular}

CSFT = Camada superficial da fáscia temporal; CPFT = Camada profunda da fáscia temporal; GA = Gordura abdominal 
A representação gráfica das curvas de VD média, para cada tipo de tecido, pode ser vista na Figura 4.

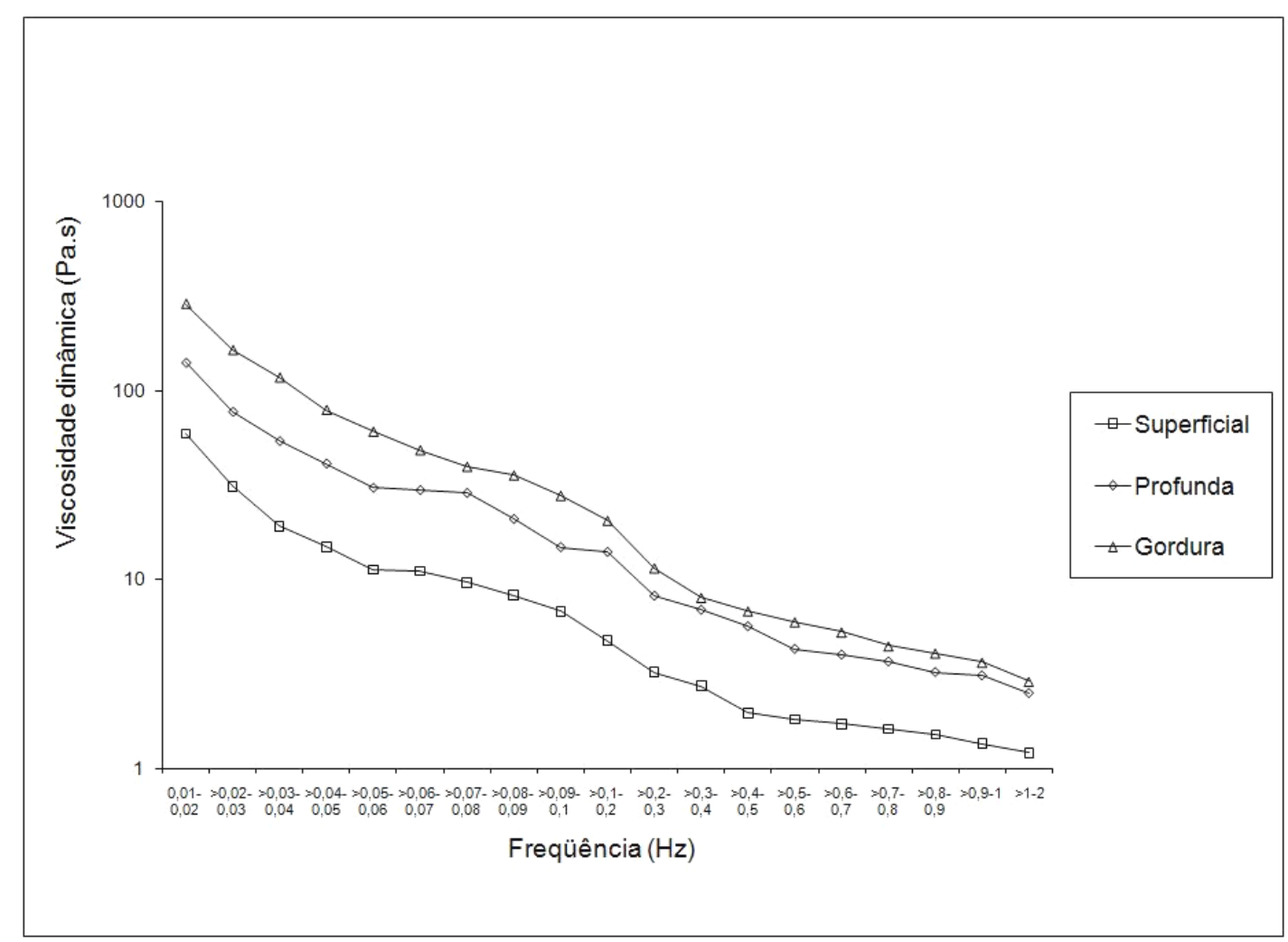

Figura 4 - Curvas de viscosidade dinâmica média $\left(\mathrm{VD}_{\mathrm{M}}\right)$ para cada tipo de tecido, para as diferentes faixas de frequência. Cada ponto representa a média dos valores da viscosidade dinâmica para 12 amostras em cada intervalo de frequência. O eixo da viscosidade dinâmica está em escala logarítmica.

A VD das diferentes amostras apresentou uma ordem crescente: CSFT, CPFT e gordura abdominal. Foi observada diferença estatisticamente significante quando comparados os valores de VD para todos os tecidos analisados (Tabela 2). 
Tabela 2 - Resultados da análise estatística em comparações múltiplas entre os valores da viscosidade dinâmica de tecidos diferentes, com relação aos intervalos de frequência.

\begin{tabular}{|c|c|c|}
\hline & $\begin{array}{c}\text { Comparação da VD } \\
\text { de dois tecidos }\end{array}$ & $\mathbf{p}$ \\
\hline CSFT $v$ & S CPFT & 0,0025 \\
\hline CSFT $v$ & $s$ GA & $<0,0001$ \\
\hline CPFT $v$ & S $\mathbf{G A}$ & 0,0006 \\
\hline
\end{tabular}

$\overline{\overline{C S F T} \text { = Camada Superficial da Fáscia Temporal; CPFT = Camada Profunda da Fáscia Temporal; GA }}$ = Gordura Abdominal; vs = versus; $\mathrm{p}=$ significância 
6 DISCUSSÃO 
O tratamento cirúrgico da rigidez da mucosa vocal tenta recuperar a lâmina própria, com enxerto de materiais biológicos ou sintéticos de modo a “criar um coxim” sobre o qual o epitélio possa vibrar facilmente e, desta maneira, produzir uma voz de melhor qualidade (Tsunoda et al., 1999; Damrose, Berke, 2003).

Há uma grande variedade de materiais que podem ser utilizados para injeções e implantes em pregas vocais, desde materiais biológicos autólogos como gordura abdominal - Brandenburg et al. (1996); fáscia temporal - Tsunoda et al. (1999); fáscia lata - Rhikanen (1998); e, combinações das anteriores - Hsiung et al. (2004) até materiais sintéticos como teflon- Tsunoda et al. (1999); colágeno - Damrose e Berke (2003) e diferentes materiais derivados do ácido hialurônico - Hertegard et al. (2002).

Muitos fatores devem ser considerados quando se escolhe um material (Chan, Titze, 1998; Hertegard et al., 2003): facilidade técnica no uso; baixo risco de imunogenicidade; baixa probabilidade de mau posicionamento; baixa reabsorção do material ao longo do tempo; baixo custo; e, principalmente, que o material colocado seja da qualidade que permita uma boa mobilidade do epitélio, o que depende, em última análise, de sua viscosidade dinâmica (VD).

A VD pode ser definida como a medida da fricção interna de um material durante deformação sinusoidal e está relacionada à resistência de determinado 
material ao fluir. A VD pode ser obtida com a utilização do reômetro de placas paralelas, em que a placa inferior é fixa. A placa superior é móvel e conectada ao eixo do equipamento. Aplica-se à placa móvel força torcional controlada por método rotacional contínuo que controla as condições de amplitude e freqüência da onda senoidal aplicada. A resistência do material à deformação aplicada é medida por sensores na placa inferior e a VD do material é calculada.

Como pode ser observado na figura 4, a VD apresentou-se como uma função decrescente da freqüência para todas as amostras, de maneira aproximadamente linear na escala logarítmica. Esse tipo de resposta foi observado em outros estudos nos quais foram medidas as propriedades viscoelásticas de materiais biológicos (Titze, 1988; Chan, Titze, 1998, 1999a, 1999b, 2008; Chan et al., 2001; Chan, Tayama, 2002; Thibeault et al., 2002; Hertegard et al., 2002, 2003, 2006; Kriesel et al., 2002; Rosseau et al., 2003; Dahlqvist et al., 2004; Klemuk, Titze, 2004; Hansen et al., 2005; Cedervall et al., 2007; Caton et al., 2007).

Também pode ser observado na Figura 4, que a VD é uma função da freqüência de oscilação. Nesse estudo, utilizamos varredura de freqüências entre $0,01 \mathrm{~Hz}$ e $2 \mathrm{~Hz}$, que é uma faixa muito menor da que ocorre na vibração da mucosa vocal durante a fonação humana (150-250Hz). Isso, no entanto, é uma limitação do método utilizado. A partir de 3Hz, efeitos inerciais (Hertegard et al., 2003) e de descolamento da amostra (“wall-slipping”) (Chan, Titze, 2000) tornam-se significantes, e a validade dos dados obtidos pode não ser confiável. Esse fenômeno ocorreu em nosso estudo em freqüências mais baixas do que em estudos similares (Hertegard et al., 2003), em que a inércia torna-se significante a partir de $15 \mathrm{~Hz}$, possivelmente por termos utilizado placas de diâmetro menor (8mm) (Chan, Titze, 
1999b; Titze et al., 2004). No entanto, a literatura demonstra que os dados obtidos em baixas freqüências em estudos reológicos de pregas vocais podem ser extrapolados para as freqüências da fonação (Chan, Titze, 2000; Chan, 2001; Chan, 2004).

Em se considerando a técnica de medição da VD com o reômetro de placas paralelas, há que se notar duas possibilidades de se definir a amplitude de espaçamento entre placas: espaçamento fixo arbitrariamente; e espaçamento definido pela compressão a que a amostra está submetida.

A utilização de espaçamento entre placas paralelas, controlado por compressão da amostra, representa uma inovação nos estudos de reometria relacionados a materiais implantáveis em laringologia. Nos artigos revisados pelos autores, foram utilizados espaçamentos fixos, isto é, definidos arbitrariamente (Titze, 1988; Chan, Titze, 1998, 1999a, 1999b, 2008; Chan et al., 2001; Chan, Tayama, 2002; Thibeault et al., 2002; Hertegard et al., 2002, 2003, 2006; Kriesel et al., 2002; Rosseau et al., 2003; Dahlqvist et al., 2004; Klemuk, Titze, 2004; Hansen et al., 2005; Cedervall et al., 2007; Caton et al., 2007). Contudo, as amostras de tecidos biológicos possuem espessuras heterogêneas e a utilização de um mesmo espaçamento para diferentes amostras de tecidos poderia resultar em diferentes níveis de compressão exercidos pelas placas sobre a mesma.

Iniciamos nosso trabalho (Wiikmann et al., 2009) pesquisando o comportamento dos tecidos a serem estudados quando submetidos a compressões diferentes. Observamos que apresentam medidas de VD diferentes em função da compressão. Dessa maneira, optamos por utilizar espaçamento entre placas definido 
por compressão fixa $(0,5 \mathrm{~N})$. A compressão de $0,5 \mathrm{~N}$ foi escolhida por ser a compressão mínima necessária para que a amostra se ajuste perfeitamente à placa e produza uma resposta sem muito ruído (com traçado regular). Porém, não se sabe qual o nível de compressão a que um implante de prega vocal é submetido em condições clínicas.

Neste estudo, utilizamos amostras frescas de tecido com até 18 horas post mortem, evitando-se possíveis alterações decorrentes da deterioração do material, e que o congelamento pudesse provocar (Chan, Titze, 2003).

Padronizamos a obtenção e manipulação dos tecidos que foram analisados, para minimizar os danos e a variabilidade entre as amostras de diferentes cadáveres. As camadas superficial e profunda da fáscia temporal foram cuidadosamente dissecadas, evitando-se comprimir as amostras.

A gordura abdominal foi obtida com o mesmo método que os autores utilizam para colher gordura abdominal para implantação em prega vocal, isto é, remoção de pequeno fragmento de gordura da camada superficial, através de pequena incisão, mantendo pequenas áreas de tecido conectivo aderido à amostra, evitando assim a manipulação excessiva do material. Foi demonstrado que os lipócitos apresentam maior chance de sobrevivência num enxerto livre de gordura, ao se manter bem estruturados, o que colabora para a diminuição da reabsorção do enxerto (Brandenburg et al., 1996). Não se sabe se processamentos diferentes nas amostras de gordura abdominal poderiam resultar em medidas de VD diferentes (Chan, Titze, 1998).

A comparação dos resultados deste estudo com outros realizados previamente 
pode ficar dificultada por diferenças metodológicas observadas. Há que se notar que, no presente estudo, a reometria foi feita utilizando-se espaçamento entre placas paralelas controlado por compressão, em contraposição com o espaçamento fixo em outros estudos (Titze, 1988; Chan, Titze, 1998, 1999a, 1999b, 2008; Chan et al., 2001; Chan, Tayama, 2002; Thibeault et al., 2002; Hertegard et al., 2002, 2003, 2006; Kriesel et al., 2002; Rosseau et al., 2003; Dahlqvist et al., 2004; Klemuk, Titze, 2004; Hansen et al., 2005; Cedervall et al., 2007; Caton et al., 2007). Dependendo da amplitude do espaçamento fixo utilizado e da espessura do tecido utilizado, poderia resultar uma compressão maior ou menor na amostra medida, quando comparada à amostra com compressão fixa. Essa diferença na compressão poderia influenciar decisivamente o valor da VD medida.

Outra dificuldade encontrada na comparação entre estudos foi a grande variabilidade de resultados de fato observada entre alguns estudos, principalmente os que se propunham a quantificar a VD de pregas vocais normais (Chan, Titze, 1999; Chan, Toyama, 2002; Wiikmann et al., 2009). A diferença da medição de VD observada numa mesma freqüência pode variar em mais de três ordens de grandeza em escala logarítmica.

De maneira geral, no entanto, alguns parâmetros puderam ser observados.

Thibeault et al., 2002 e Rousseau et al., 2003 produziram lesões em cordas vocais de animais e observaram que a VD de pregas vocais lesadas apresentou-se maior que de pregas vocais controles.

Ainda em modelos de animais submetidos a lesão de pregas vocais, foram realizados estudos para avaliar se o uso de determinadas substâncias poderia 
apresentar melhor prognóstico em termos de VD (isto é, se a utilização de tais substâncias poderia produzir pregas vocais com VD menor), quando comparadas a pregas vocais lesadas controles. A injeção de colágeno não se mostrou superior ao controle (Kriesel et al., 2002), mas a aplicação de ácido hialurônico se mostrou superior ao controle (Hansen et al., 2005). Também tentou-se a utilização da biologia molecular para reestabelecer a VD após a lesão da prega vocal. A aplicação de células tronco mesenquimais humanas não se mostrou superior ao controle (Hertegard et al. 2006), contudo a utilização de células tronco embrionárias se mostrou superior ao controle (Cedervall et al., 2007).

A pesquisa da VD de materiais implantáveis em pregas vocais também foi objeto de alguns estudos (Chan, Titze, 1998; Chan, Titze, 1999; Hertegard et al., 2003; Klemuk, Titze, 2004; Dalhqvist et al. 2004; Caton et al., 2007). Seus resultados apontam para a seguinte ordem crescente de VDs: compostos de ácido hialurônico; gordura abdominal; colágeno implantável e compostos; gelfoam; e, teflon. Por esses achados, os melhores materiais para serem implantados para recuperação da mobilidade das pregas vocais seriam o ácido hialurônico e a gordura abdominal. Considerando as vantagens de disponibilidade e custos, a gordura abdominal nos parece ser a melhor opção disponível.

Nesse estudo observamos que a VD da gordura abdominal foi maior do que a VD da camada profunda e da camada superficial fáscia temporal. Apesar de todos os problemas decorrentes da comparação de estudos com métodos diferentes, podemos considerar que as camadas da fáscia temporal apresentam VD menor que muitos materiais utilizados para implantes e injeções em pregas vocais (pois têm VD menores que a da gordura abdominal). 
Como já referimos, o enxerto ideal para restabelecer a vibração da mucosa da prega vocal deve apresentar baixa viscosidade. Nesse estudo, a CSFT, apresentou viscosidade mais baixa que outros tecidos autólogos tradicionalmente utilizados em implantes em pregas vocais (CPFT e gordura abdominal) e isso representa uma possível vantagem na utilização deste material. No entanto, seria interessante comparar a VD da CSFT, uma vez que apresentou as menores medidas no nosso estudo, com a de compostos de ácido hialurônico.

Na comparação com materiais sintéticos, outra possível vantagem da CSFT é que, por ser obtida do próprio paciente, não deve representar risco de reação tipo corpo-estranho ou imunomediada. Além disso, é de baixo custo. Como desvantagem, pode-se citar a necessidade de incisão retroauricular para obtenção do enxerto.

A utilização de CSFT como material implantável em laringe é uma técnica promissora, levando-se em conta a VD baixa do material quando comparado com outros tecidos tradicionalmente utilizados nesses procedimentos. Outros estudos experimentais e clínicos devem ser realizados para que outros fatores como facilidade de uso, potencial de reabsorção, integração do enxerto e resultado em termos de qualidade vocal sejam avaliados. 
6 CONCLUSÃO 
A camada superficial da fáscia temporal apresenta medidas de viscosidade dinâmica menores que a camada profunda da fáscia temporal e gordura abdominal. 
REFERÊNCIAS BIBLIOGRÁFICAS 


\section{REFERÊNCIAS BIBLIOGRÁFICAS ${ }^{1}$}

Brandenburg JH, Unger JM, Koschkee D. Vocal cord injection with autogenous fat: a lomg-term magnetic resonance imaging evaluation. Laryngoscope. 1996;106:174-80.

Caton T, Thibeault SL, Klemuk S, Smith ME. Viscoelasticity of hyaluronan and nonhyaluronan based vocal fold injectables: implications for mucosal versus muscle use. Laryngoscope. 2007;117:516-21.

Cedervall J, Ährlund-Richter L, Svensson B, Forsgren K, Maurer F, Vidovska D, Hertegard S. Injection of embryonic stem cells into scarred rabbit vocal folds enhances healing and improves viscoelasticity: short-term results. Laryngoscope. 2007;117:2075-81.

Chan RW. Estimation of viscoelastic shear properties of vocal fold tissues based on time-temperature superposition. J Acoust Soc Am. 2001;110:1548-61.

Chan RW. Measurements of vocal fold tissue viscoelasticity: approaching the male phonatory frequency range. J Acoust Soc AM. 2004;115:3161-70.

Chan RW, Gray SD, Titze IR. The importance of hyaluronic acid in vocal fold biomechanics. Otolaryngol Head Neck Surg. 2001;124:607-14.

${ }^{1}$ De acordo com:

Adaptado de International Committee of Medical Journals Editors (Vancouver).

Universidade de São Paulo. Faculdade de Medicina. Serviço de Biblioteca e Documentação. Guia de apresentação de dissertações, teses e monografias da FMUSP. Elaborado por Anneliese Carneiro da Cunha, Maria Julia A.L. Freddi, Maria F. Crestana, Marinalva de S. Aragão, Suely C. Cardoso, Valéria Vilhena. 2a ed. São Paulo: Serviço de Biblioteca e Documentação; 2005.

Abreviaturas dos títulos dos periódicos de acordo com List of Journals Indexed in Index Medicus. 
Chan RW, Tayama N. Biomechanical effects of hydration in vocal fold tissues. Otolaryngol Head Neck Surg. 2002;126:528-37.

Chan RW, Titze IR. Effect of postmortem changes and freezing on the viscoelastic properties of vocal fold tissues. Ann Biom Eng. 2003;31:482-91.

Chan RW, Titze IR. Hyaluronic acid (with fibronectin) as a bioimplant for the vocal fold mucosa. Laryngoscope. 1999a;109:1142-9.

Chan RW, Titze IR. Viscosities of implantable biomaterials in vocal fold augmentation surgery. Laryngoscope. 1998;108:725-31.

Chan RW, Titze IR. Viscoelastic shear properties of human vocal fold mucosa: measurement methodology and empirical results. $J$ Acoust Soc Am. 1999b;106:2008-20.

Chan RW, Titze IR. Viscoelastic shear properties of human vocal fold mucosa: theoretical characterization based on constitutive modeling. J Acoust Soc Am. 2000;107:565-80.

Costa JO, Gama AC, Oliveira JB, Rezende Neto AL. Acoustical analysis and perceptual ratings of voice before and after surgery for implantation of pre-fascia temporal muscle. Rev CEFAC. São Paulo 2008;10:76-83.

Dahlqvist A, Gärskog O, Laurent C, Hertegard S, Ambrosio L, Borzacchiello A. Viscoelasticity of rabbit vocal folds after injection augmentation. Laryngoscope. 2004;114:138-42.

Damrose EJ, Berke GS. Advances in the management of glottic insufficiency. Curr Opin Otolaryngol Head Neck Surg. 2003;11:480-4. 
Finkelhor BK, Titze IR, Durham PL. The effect of viscosity changes in the vocal folds on the range of oscillation. $J$ Voice. 1987;1:320-5.

Hansen JK, Thibeault SL, Walsh J, Shu XZ, Prestwich GD. In vivo engineering of the vocal fold extracellular matrix with injectable hyaluronic acid hydrogels: early effects on tissue repair and biomechanics in a rabbit model. Ann Otol Rhinol Laryngol. 2005;114:662-70.

Hertegard S, Cedervall J, Svensson B, Forsberg K, Maurer J, Vidovska D, Olivius P, Ährlund-Richter L, Le Blanc K. Viscoelastic and histologic properties in scarred rabbit vocal folds after mesenchymal stem cell injection. Laryngoscope. 2006;116:1248-54.

Hertegard S, Dahlqvist A, Laurent C, Borzacchiello A, Ambrosio L. Viscoelastic properties of rabbit vocal folds after augmentation. Otolaryngol Head Neck Surg. 2003;128:401-6.

Hertegard S, Hallen L, Laurent C, Lindstrom E, Olofsson K, Dahlqvist A. Crosslinked hyaluran used as augmentation substance for treatment of glottal insufficiency: safety aspects and vocal fold function. Laryngoscope. 2002;112:2211-9.

Hsiung MW, Kang BH, Pai L, Su WF, Lin YH. Combination of fascia transplantation and fat injecton into the vocal fold for sulcus vocalis: long-term results. Ann Otol Rhinol Laryngol. 2004;113:359-66.

Klemuk SA, Titze IR. Viscoelastic properties of three vocal fold injectable biomaterials at low audio frequencies. Laryngoscope. 2004;114:1597-603.

Kriesel KJ, Thibeault SL, Chan RW, Suzuki T, VanGroll PJ, Bless DM, Ford CN. Treatment of vocal fold scarring: rheological and histological measures of homologous collagen matrix. Ann Otol Rhinol Laryngol. 2002;111:884-9. 
Rhikanen H. Vocal fold augmentation by injection of autologus fascia. Laryngoscope. 1998;108:51-4.

Rousseau B, Hirano S, Scheidt TD, Welham NV, Thibeault SL, Chan RW, Bless DM. Characterization of vocal fold scarring in a canine model. Laryngoscope. 2003;113:620-7.

Thibeault SL, Gray SD, Bless DM, Chan RW, Ford CN. Histologic and rheologic characterization of vocal fold scarring. $J$ Voice. 2002;16:96-104.

Titze IR. The physics of small-amplitude oscillation of the vocal folds. $J$ Acoust Soc Am. 1988;83:1536-52.

Titze IR, Klemuk SA, Gray S. Methodology for rheological testing of engineered biomaterials at low audio frequencies. J Acoust Soc Am. 2004;115:392-401.

Tsunoda K, Takanosawa M, Niimi S. Autologus transplantation of fascia into the vocal fold: a new phonosurgical technique for glottal incompetence. Laryngoscope. 1999;109:504-8.

Wiikmann C, Silva MA, Areas EPG, Tsuji DH, Sennes LU. Measurement of viscoelastic properties of vocal folds. Ann Otol Rhinol Laryngol. 2009;118:461-4. 
APÊNDICE 


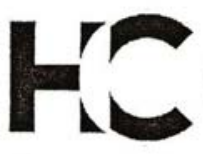

\section{APROVACEÃO}

A Comissão de Ética para Análise de Projetos de Pesquisa - CAPPesq da Diretoria Clínica do Hospital das Clínicas e da Faculdade de Medicina da Universidade de São Paulo, em sessão de 26.01.06, APROVOU o Protocolo de Pesquisa $n^{\circ}$ 1165/05, intitulado: "Avaliação de propriedades viscoelásticas da camada superficial da fáscia temporal de cadáveres para utilização em implantes de pregas vocais." apresentado pelo Departamento de OFTALOMOLOGIA E OTORRINOLARINGOLOGIA.

Cabe ao pesquisador elaborar e apresentar à CAPPesq, os relatórios parciais e final sobre a pesquisa (Resolução do Conselho Nacional de Saúde n 196, de 10.10.1996, inciso IX. 2, letra "c")

Pesquisador(a) Responsável: Prof. Dr. Luiz Ubirajara Sennes

CAPPesq, 26 de Janeiro de 2006.

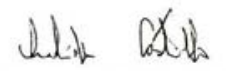

PROF. DR. EUCLIDES AYRES DE CASTILHO Presidente da Comissão de Ética para Análise de Projetos de Pesquisa

\footnotetext{
Comissão de Ética para Análise de Projetos de Pesquisa do HCFMUSP e da FMUSP

Diretoria Clinica do Hospital das Clínicas da Faculdade de Medicina da Universidade de São Paulo

Rua Ovidio Pires de Campos. 225, $5^{\circ}$ andar - CEP 05403010 - Sđo Paulo - SP

Fone: 011 - 30696442 fax : 011 - 30696492 - e-mail : cappesq@henet.usp.br / secretariacappesq@henet.usp.br
} 